\title{
Regional correlations of COVID-19 in Spain
}

\author{
Daniel Oto-Peralías \\ Universidad Pablo de Olavide
}

May 2020

\begin{abstract}
This paper analyzes the correlation between confirmed cases of COVID-19 and several geographic, meteorological and socioeconomic variables at the province level in Spain. The results indicate that there is a strong and robust negative relationship between average temperature and the rate of cases of COVID-19. The explanatory power of other geographic and socioeconomic variables is much lower. A parsimonious model including population density and temperature is able to explain $67 \%$ of variation in cases of COVID. However, the results are inconclusive regarding the existence of a relationship between changes in temperature and changes in COVID cases, casting doubts on the existence of a negative link between temperature and the spread of the virus.
\end{abstract}

Daniel Oto-Peralías. Departamento de Economía, Métodos Cuantitativos e Historia Económica. Universidad Pablo de Olavide, Seville, Spain. E-mail: dotoper@upo.es. 


\section{Introduction}

This paper analyzes the correlation between confirmed cases of COVID-19 and several geographic, meteorological and socioeconomic variables at the province level in Spain. The incidence of COVID-19 greatly varies across the Spanish provinces. Based on the data as of April 1, the accumulated case rate per 100,000 inhabitants in Soria, the province with the highest incidence, is 18 times higher than that of Almería, the one with the lowest incidence. As of May 1, the ratio between the province with the highest and lowest incidence had increased to 31. Figure 1 shows the value of the accumulated case rate for each province, while Map 1 represents it geographically.

Given these large provincial differences, it is worth asking what factors can explain them. Are the provinces with the highest COVID-19 rate the most populated? The ones that receive more tourists? The coldest? The objective of this paper is to analyze the relationship at the provincial level between the incidence of COVID-19 and several meteorological, geographic and socioeconomic factors. ${ }^{1}$ It goes without saying that what I show below are correlations and I will limit myself to interpret them as such.

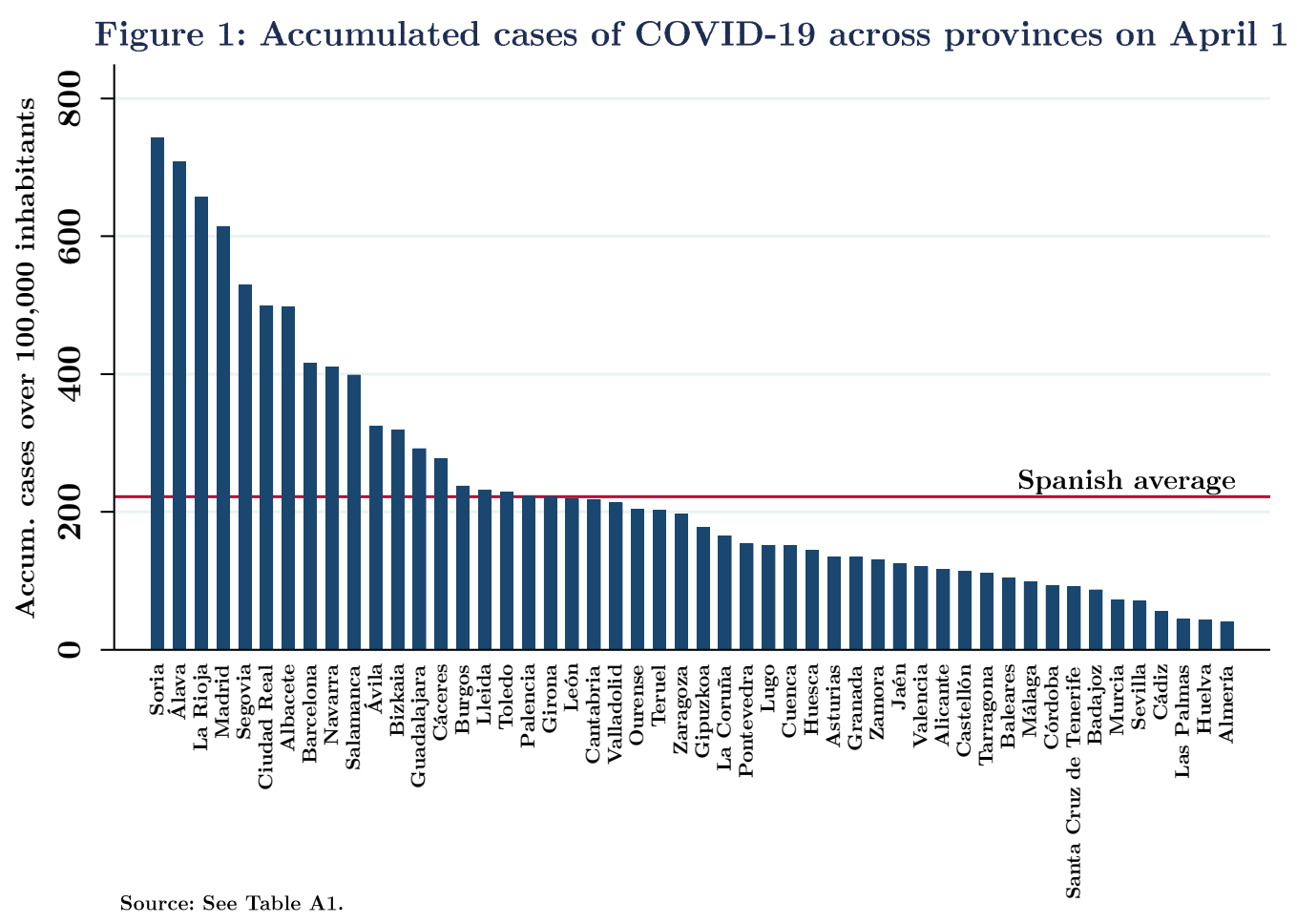

\footnotetext{
${ }^{1}$ See Orea and Álvarez (2020) for a study on the effect of confinement measures on the spread of coronavirus in Spain.
} 
The correlation between cases and deaths of COVID-19 is high, with $p=0.88$ or 0.90 in logs. Figure 2 shows the relationship between both variables. The rest of the paper uses the logarithmic transformation as its distribution is closer to a normal one, avoiding the influence of high values (see Figure 3).

Map 1: Accumulated cases of COVID-19 across provinces on April 1

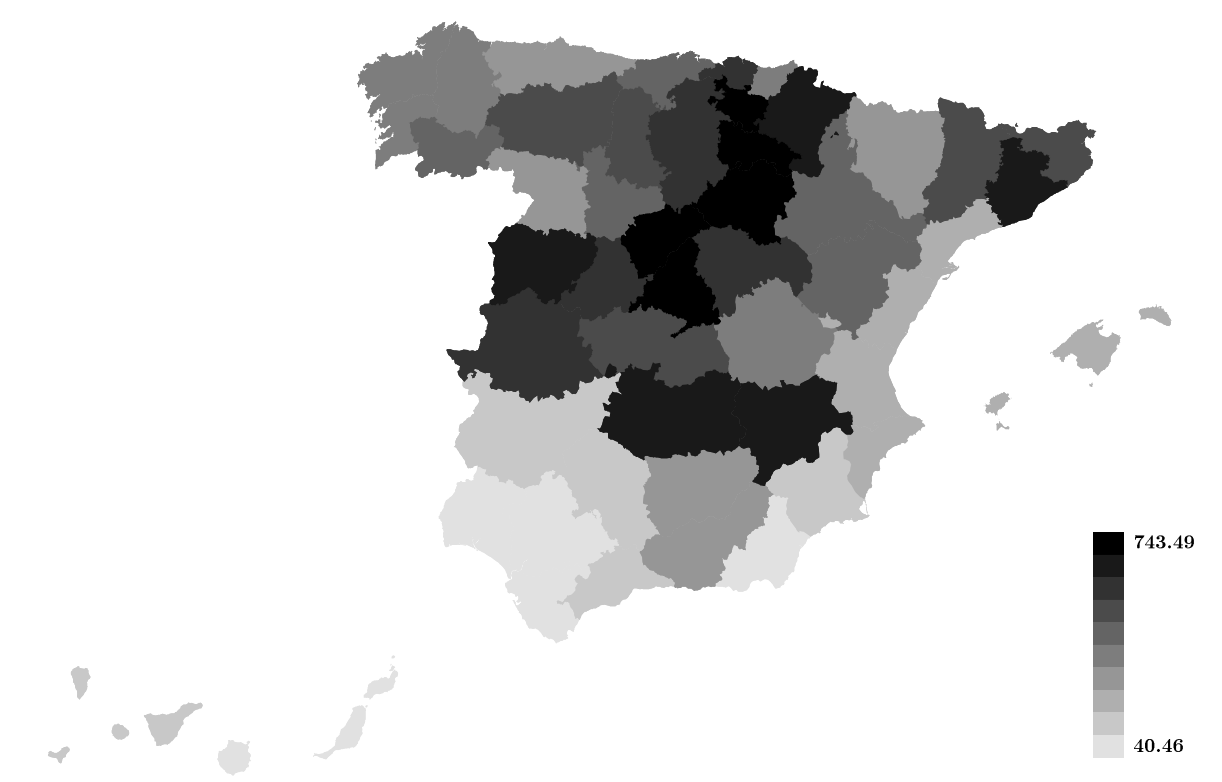

Source: See Table A1.
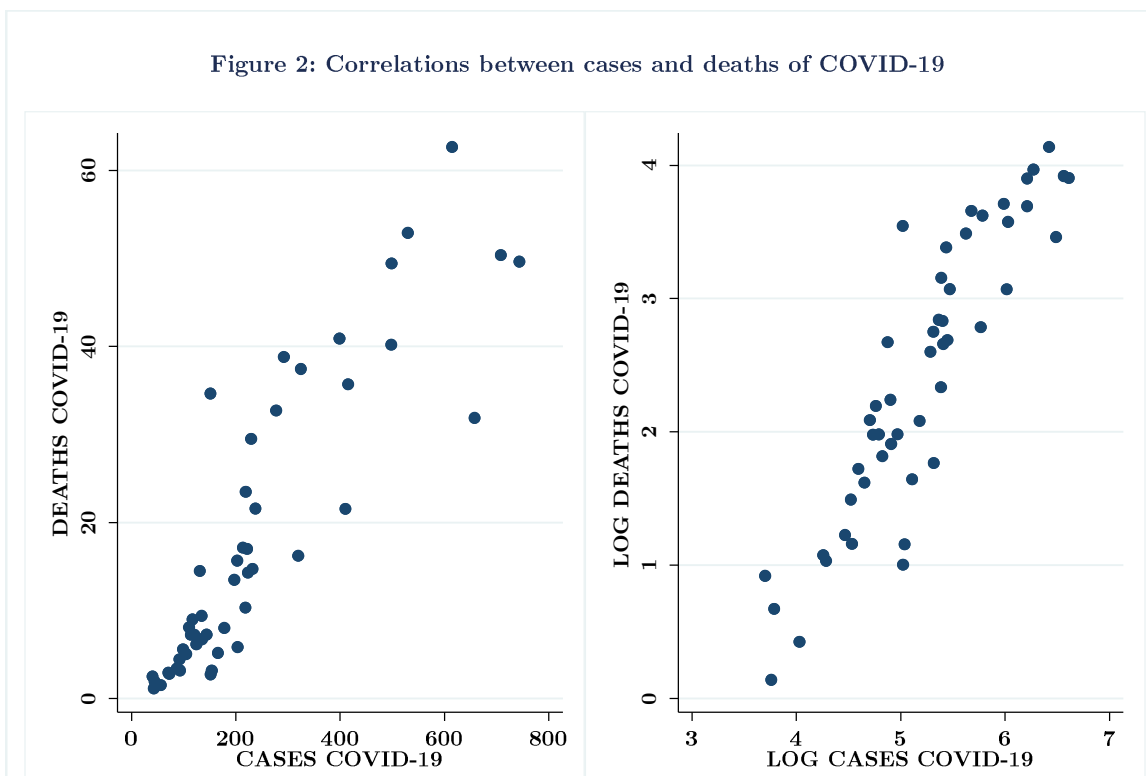

Source: See Table A1. 
Figure 3: Distribution of the variables cases and deaths of COVID-19 per 100.000 inhabitants
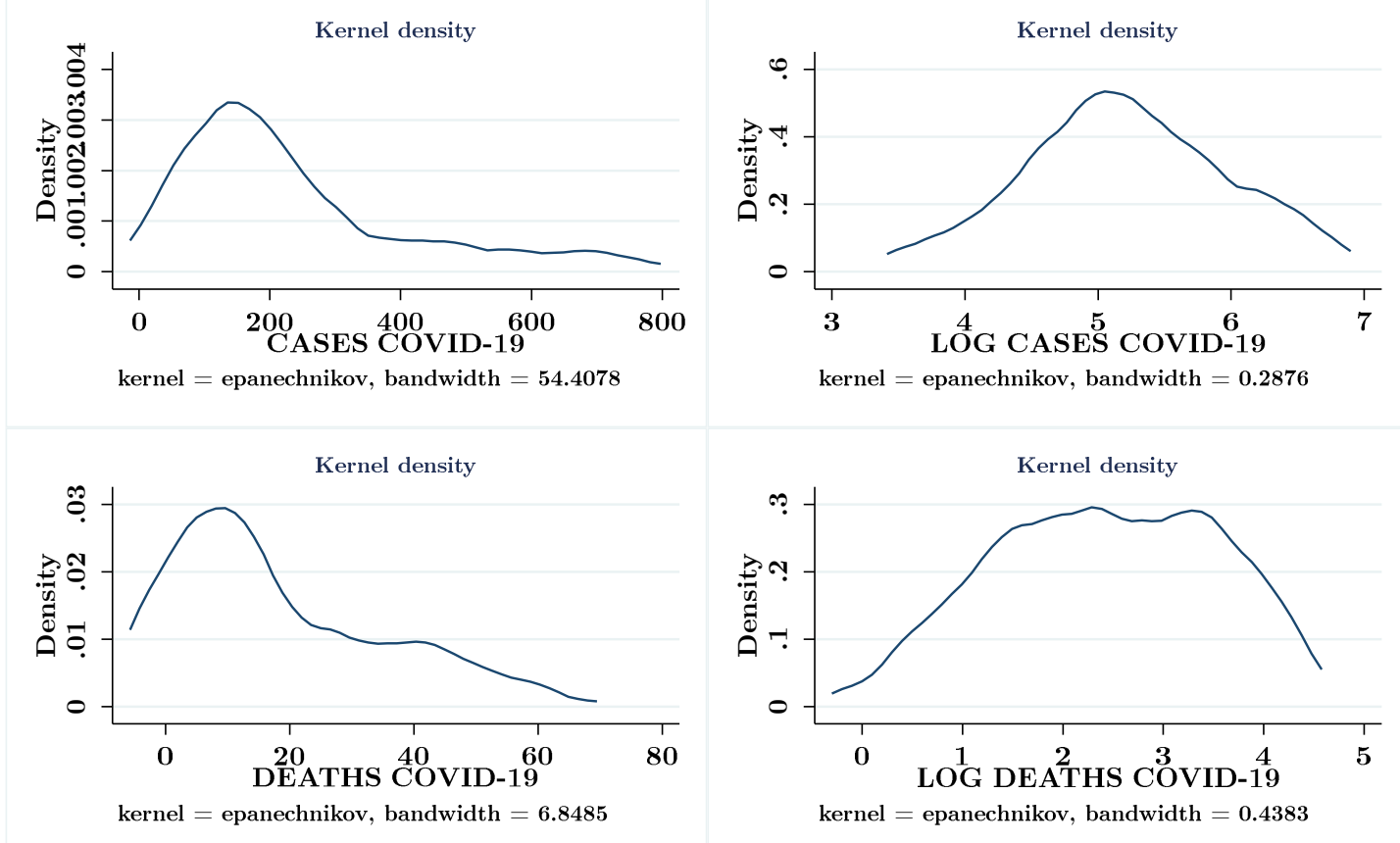

Source: See Table A1.

\section{Analysis}

\subsection{Geographic and meteorological variables}

Figure 4 depicts the relationship between COVID-19 cases on April 1 and the following geographic and meteorological variables: latitude, longitude, average temperature and rainfall during February and March of 2020, average altitude, coefficient of variation of altitude, being an island, being a coastal province, and (log) distance to Madrid. It can be seen that the northernmost and coldest provinces, those with a higher average altitude, flatter, landlocked and closer to Madrid have on average a higher incidence of COVID19. The correlation is particularly strong in the case of temperature. Table 1, which reports the coefficients from these bivariate relationships, shows that the $\mathrm{R}^{2}$ associated with temperature is twice that of the variable that follows it in explanatory power. The average temperature recorded during February and March of this year explains $59 \%$ of the variation in the rate of cases of COVID. Another interesting relationship is the one observed with distance to Madrid. Provinces closer to Madrid have, on average, a higher 
rate of accumulated cases -although this correlation disappears when controlling for temperature.

Figure 4: Correlations between the rate of COVID-19 cases and several geo-climatic variables
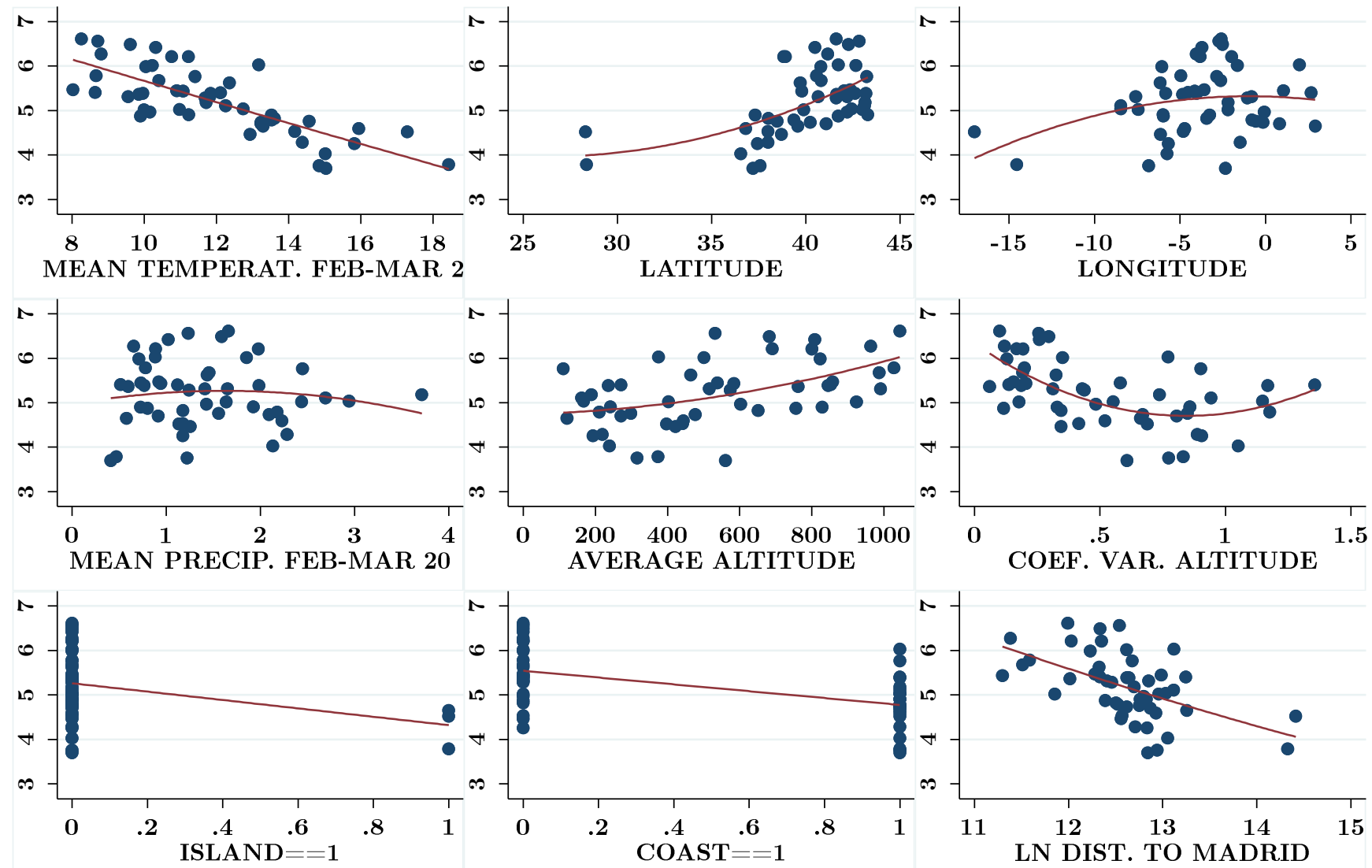

COEF. VAR. ALTITUDE

Notes: The variable on the $\mathrm{Y}$ axis is always the log of accumulated cases of COVID19/100000 inhab. on April 1. Madrid is omitted when using distance to Madrid. Sources: See Table A1

The negative correlation between COVID-19 cases and temperature is consistent with other observational studies (for instance, Coccia, 2020; Qi et al., 2020, Wang et al., $2020)^{2}$, but is this provincial correlation robust when other geographic variables are taken into account? Column 10 of Table 1 shows that this is, in fact, the case: when all the variables are included together, only temperature is statistically significant (distance to Madrid is marginally significant). Column 11 removes latitude and longitude as they (particularly latitude) are correlated with other regressors and do not capture any specific geographic or climatic factor by themselves -beyond obviously the northward and eastward location. Only temperature and distance to Madrid are statistically significant.

\footnotetext{
2 Some preliminary results at the regional (autonomous community) level in Spain also suggest a negative relationship between temperature and cases of COVID-19 (Ministerio de Ciencia, 2020).
} 
The two previous regressions contain some variables related to each other, generating multicollinearity. An alternative way to choose the variables to include is through the stepwise method, which progressively selects a model based on the statistical significance of the variables. This method leads to a model that only includes temperature, which suggests that it is the most relevant factor (column 12). If we exclude the Canary Islands, which is an overseas territory that may behave differently, the model also includes distance to Madrid. ${ }^{3}$

Table 2 focuses on the relationship between temperature and the rate of COVID-19 cases. Columns 1 to 9 show that the coefficient is very stable when including the other geographic variables one by one. The negative relationship is not affected either when Canarias and Madrid are excluded in columns 10 and 11. The introduction of a set of 17 dummy variables, one for each autonomous community in Spain, does not negate the effect of temperature.

Table 3 assesses the robustness of the negative correlation between distance to Madrid and COVID-19. Column 1 shows the bivariate relationship, while the next column excludes Madrid itself (resulting in the same regression as in column 9, Table 1). Column 3 excludes the Canary Islands and column 4 further excludes Madrid. The coefficient remains large and highly statistically significant to these changes. However, if we add temperature to the last model, distance to Madrid becomes insignificant.

\subsection{Socioeconomic variables}

Figure 5 depicts the relationship between the rate of COVID-19 cases and a set of socioeconomic variables, namely: total population and population density in 2019 (both in log.), GDP per capita in 2017 (log.), population concentration (the percentage of the population living in the most populous $10 \%$ of the territory), air pollution in 2018 (measured as the annual average of particles less than 10 and $2.5 \mu \mathrm{m}$ ), percentage of population older than 64 years in 2019, percentage of workers in different branches of activity in 2017 (agriculture, industry and commerce-restaurants-hotels) ${ }^{4}$, number of airline passengers in February and March 2020 and the same number relative to the

\footnotetext{
3 The forward and backward selection estimations render the same results.

4 The variable measuring the percentage of employment in commerce, restaurants and hotels refers to the activity branches $\mathrm{G}$ to $\mathrm{J}$ according to the Statistical Classification of Economic Activities in the European Community (NACE).
} 
province population (both in log.). ${ }^{5}$ Table 4 reports the coefficients on the linear relationship between cases of COVID-19 and the twelve variables included in the figure.

First, it is interesting to note that correlations are weaker than in the case of geographic and meteorological variables. In some cases, the sign of the correlation is counterintuitive, although it must be borne in mind that they are bivariate relationships and it is difficult to interpret them on their own, without considering the effect of other factors.

Figure 5: Correlations between the rate of COVID-19 cases and several socioeconomic variables
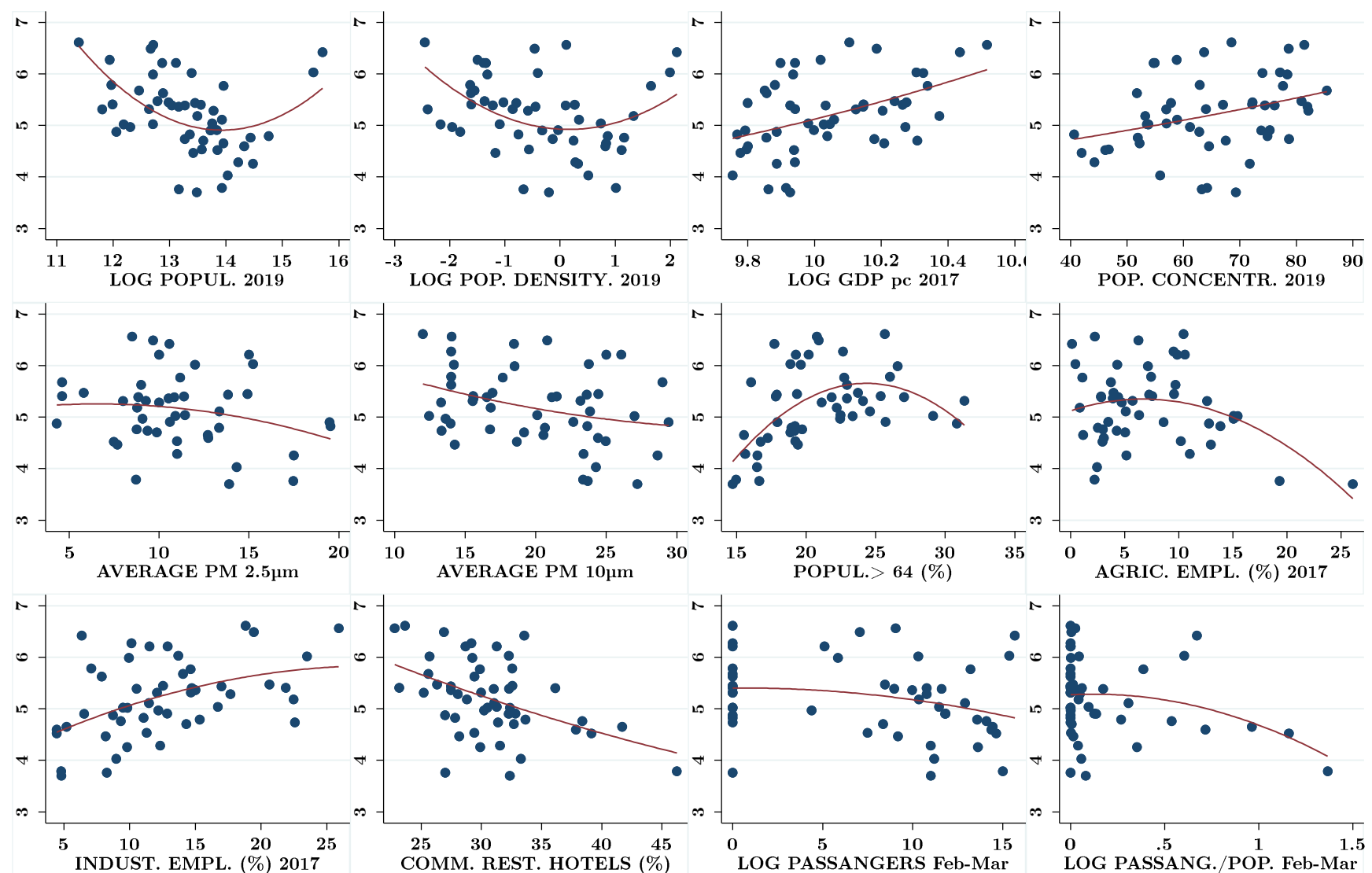

Notes: The variable on the $\mathrm{Y}$ axis is always the log of accumulated cases of COVID19/100000 inhab. on April 1. Sources: See Table A1.

Column 1 of Table 5 includes all the socioeconomic controls together, where only GDP per capita enters with a statistically significant coefficient. To avoid multicollinearity problems, I use again the stepwise method, which in column 2 leads to a model with GDP per capita and the percentage of population above 64 carrying positive coefficients, and

\footnotetext{
${ }^{5}$ I have also calculated the following indicators: population density of the $10 \%$ most populated of the territory, log GDP, and log GDP intensity (that is, GDP/surface area). However, these variables are not used in the analysis because they are highly correlated with population density and total population.
} 
the percentage of employment in commerce, restaurants and hotels carrying a negative one. ${ }^{6}$ Column 3 reruns the same regression as in column 1 but adding temperature as a basic control. Interestingly, the latter enters with a large and statistically significant coefficients while the only (marginally) significant coefficient among the socioeconomic variables is population density. Finally, column 4 runs the stepwise method including temperature as a compulsory control, rendering a parsimonious model with population density that explains $67 \%$ of the variation in COVID-19 cases. The conditional relationships (from this last model) of the rate of COVID cases with temperature and population density are represented in Figure 6.

Figure 6: Conditional relationships of COVID-19 cases with temperature and population density
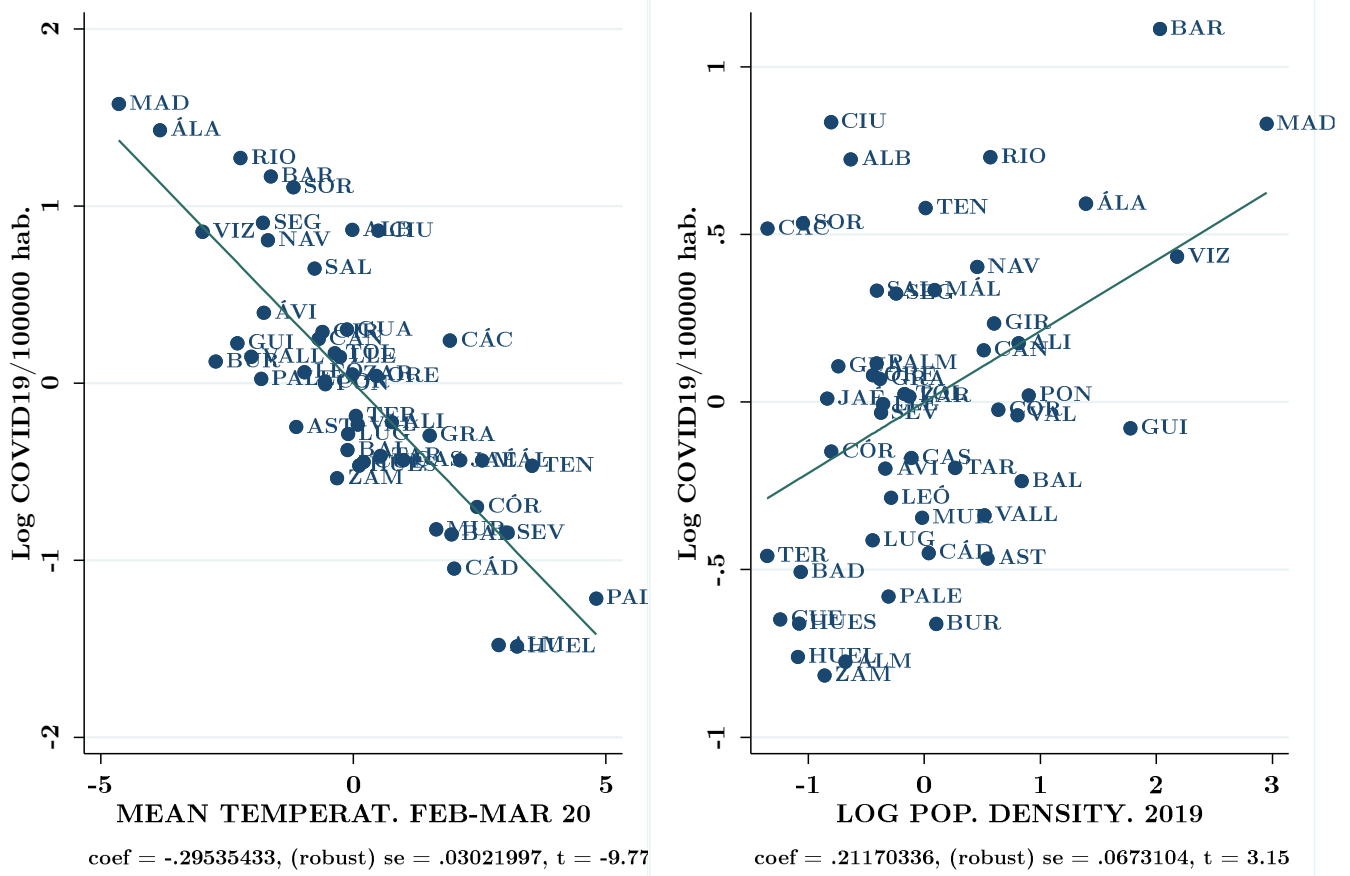

\subsection{Cases of COVID-19 before the confinement}

The results so far correspond to the rate of COVID-19 cases on April 1 as a benchmark date. Therefore, the above correlations can be interpreted as the cross-sectional relationship between each factor and the reception and spread of the virus during the months of February and March. However, a strict confinement was enacted by the Spanish government -together with the establishment of the state of emergency- on

${ }^{6}$ The forward and backward selection estimations render the same results. 
March 14 (coming into force the next day), and this measure may have affected the correlations reported above. Therefore, it is relevant to redo the analysis using the rate of cases on March 15. The correlation of the rate of COVID-19 cases between April 1 and March 15 is 0.71 , which is a relatively high value but leaves room for changes among provinces. For this analysis, I calculate the average temperature and rainfall for the period from February 1 to March 15.

Tables 6 to 10 provide the results. The explanatory power of the geographic and socioeconomic variables is in general significantly lower. Particularly, the coefficient on temperature is smaller in size and less robust, losing importance against distance to Madrid. These different results may be because i) it is more difficult to explain the incidence of COVID-19 at an earlier stage of the epidemic, ii) the influence of the confinement measures, or iii) more measurement errors in March 15 than in April 1.

\subsection{Changes in the rate of COVID-19 cases}

I turn now to analyze the correlations with changes in COVID-19 cases by using as dependent variable the difference in (the log of) the rate of cases between two dates. This difference actually means the rate of new cases accumulated during the specified period. Table 11 reports the results. In most of the regressions the sample consists of 46 observations as the four Galician provinces have missing data. On the left (Panel A), temperature is included without lags, while on the right (Panel B) temperature is lagged 10 days to allow for an incubation period of coronavirus. All regressions include the log of COVID-19 cases at the beginning of each period since the increase in cases is expected to depend on its initial value, that is, to take into account the dynamics of the epidemic.

The top part of the table analyzes the relationship between changes in COVID cases (i.e., new cases) during a specific period and average temperature during the same period. I consider four periods: May 1 - April 1; April 1 - March 15; April 15 - April 1; May 1 - April 15. Remarkably, the negative relationship between changes in COVID-19 cases and temperature is very robust. Considering column 1 in Panel A, provinces that have experienced a higher average temperature during April have had a lower rate of new COVID cases. More specifically, one Celsius degree increase in temperature is associated with a $13 \%$ decrease in the rate of new cases (i.e., $e^{-0.136}-1$ ). 
The middle part of Table 11 reports results from regressions of changes in COVID cases on changes in temperature, controlling for initial cases. In contrast to previous results, there is no relationship between changes in temperature and new COVID-19 cases, no matter if temperature is temporarily lagged or not. This suggests that there is no relationship within provinces between temperature and COVID cases. In other words, provinces that have experienced a larger increase in temperature do not tend to have had a lower increase in COVID cases.

The bottom part of the table adds average temperature in the previous period to control for "initial" temperature -in the same way as I control for initial cases. The new variable enters with a large and statistically significant negative coefficient, leading to a large increase in $\mathrm{R}^{2}$. This suggests that it is a relevant variable for the model. Once this variable has been added, changes in temperature are now negatively related to changes in COVID cases. The negative coefficient is more robust when temperature variables are lagged 10 days. Regarding the interpretation of the relationship, according to column 9 (Panel A), one Celsius degree increase in temperature (regarding the previous period) is associated with a $11 \%$ reduction in the rate of new cases. Figure 7 represents the conditional correlations between temperature and changes in COVID cases reported in columns 1, 5 and 9 in Panel A.

Therefore, the existence or not of a relationship between temperature and COVID cases depends on the specific model selected. Concerning the lack of a robust correlation between new COVID cases and changes in temperature, it may be due to the fact that the existing variation across provinces is larger than within provinces. For instance, the range in values of mean temperature in April is 7.9 while the range of the change in temperature between April and March is 3.7 (i.e., less than half). Therefore, although the evidence is inconclusive regarding the link between changes in temperature and new COVID-19 cases, this arguably does not rule out that big changes in temperature as a result of the summer heat may hinder the spread of the virus. ${ }^{7}$

\footnotetext{
${ }^{7}$ This inconclusive evidence is consistent with Briz-Redón and Serrano-Aroca (2020) who find no relationship between temperature and COVID incidence in another study of Spanish provinces.
} 

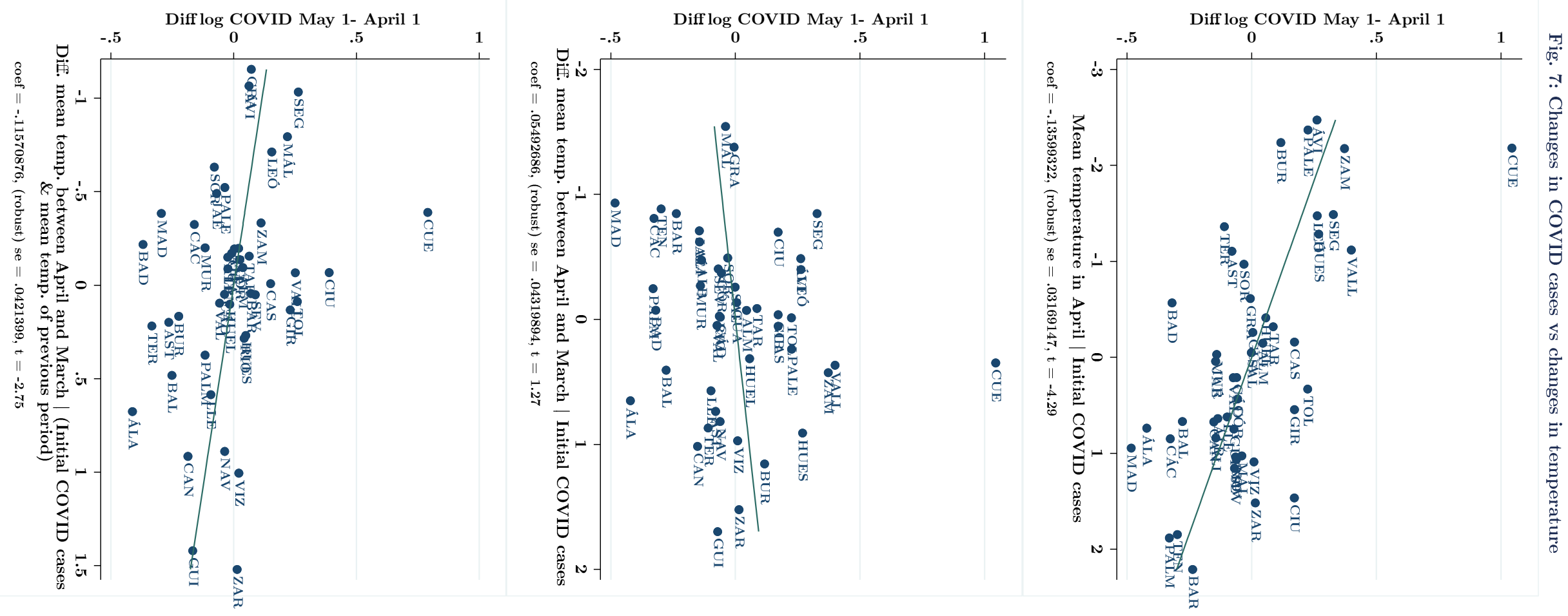


\subsection{The rate of deaths related to COVID-19}

I have replicated Tables 1 to 5 using as dependent variable the rate of deaths related to COVID-19 over 100,000 inhabitants on April 1. The results, reported in the Appendix, are similar to the ones in Tables 1 to 5, particularly concerning geographic and meteorological variables. This does not come as a surprise as COVID cases and deaths are highly correlated $(p=0.9) .^{8}$

\section{Conclusions}

This short paper conducts a correlational analysis between the incidence of COVID-19 and a wide range of meteorological, geographic, and socioeconomic variables. While correlations with socioeconomic variables are not stable across specifications and are sometimes counter-intuitive, the correlations with temperature and distance to Madrid, both negative, are more interesting. The one with temperature is particularly robust. Temperature (in levels) is negatively related both to COVID cases and to changes in COVID cases. However, the evidence on the correlation between changes in temperature and changes in COVID cases is inconclusive, which casts doubts on the role that the arrival of the summer heat may play in limiting the spread of the virus. This ambiguous result is in line with the view of experts in the field, who point out that the heat, while it may reduce the efficiency with which it is transmitted, will not necessarily stop the coronavirus (EL PAÍS, 2O2O). More data (over a longer period of time) will help assess the real relationship between temperature and COVID-19 cases.

\section{References}

Briz-Redón, Álvaro, and Ángel Serrano-Aroca. 2020. "A spatio-temporal analysis for exploring the effect of temperature on COVID-19 early evolution in Spain." Science of The Total Environment, 138811.

Coccia, Mario. 2020. "Diffusion of COVID-19 Outbreaks: The Interaction between Air Pollution-to-Human and Human-to-Human Transmission Dynamics in Hinterland Regions with Cold Weather and Low Average Wind Speed." Working Paper CocciaLab n. 48/2020, CNR - National Research Council of Italy.

\footnotetext{
8 The data used in the analysis is available at sites.google.com/site/danielotoperalias/research/others
} 
EL PAÍS (2020). "El verano no derrotará al coronavirus". April 16, 2020. https://elpais.com/ciencia/2020-04-15/el-verano-no-derrotara-al-coronavirus.html

Ministerio de Ciencia (2020). "Primeros indicios de correlación entre variables meteorológicas y propagación de la enfermedad COVID-19 y del virus SARS-CoV-2 en España". April 14, 2020- https://t.co/HQjjjrO707?amp=1

Orea, L., and Álvarez, I. C. (2020). "How effective has the Spanish lockdown been to battle COVID-19? A spatial analysis of the coronavirus propagation across provinces". FEDEA Documento de Trabajo, 03.

Qi, Hongchao, et al. 2020. "COVID-19 transmission in Mainland China is associated with temperature and humidity: a time-series analysis." Science of The Total Environment, 138778.

Wang, Jingyuan and Tang, Ke and Feng, Kai and Lv, Weifeng (2020). "High Temperature and High Humidity Reduce the Transmission of COVID-19," Available at SSRN: http://dx.doi.org/10.2139/ssrn.3551767 
TABLES

Table 1

Depedent variable: Log of accumulated cases of COVID19/100000 inhab. on April 1, 2020

Step-wise

Step-wise w/o

Canarias

\begin{tabular}{|c|c|c|c|c|c|c|c|c|c|c|c|c|c|}
\hline & 1 & 2 & 3 & 4 & 5 & 6 & 7 & 8 & 9 & 10 & 11 & 12 & 13 \\
\hline MEAN TEMPERAT. & $-0.236^{* * *}$ & & & & & & & & & $-0.238^{* *}$ & $-0.218^{* * *}$ & $-0.236^{* * *}$ & $-0.228^{* * *}$ \\
\hline FEB-MAR 20 & $(0.029)$ & & & & & & & & & $(0.108)$ & $(0.041)$ & $(0.029)$ & $(0.037)$ \\
\hline \multirow{2}{*}{ LATITUDE } & & $0.13^{* * *}$ & & & & & & & & -0.023 & & & \\
\hline & & $(0.028)$ & & & & & & & & $(0.078)$ & & & \\
\hline \multirow{2}{*}{ LONGITUDE } & & & $0.053^{* *}$ & & & & & & & 0.016 & & & \\
\hline & & & $(0.023)$ & & & & & & & $(0.023)$ & & & \\
\hline MEAN PRECIP. FEB- & & & & -0.029 & & & & & & 0.137 & 0.116 & & \\
\hline MAR 20 & & & & $(0.127)$ & & & & & & $(0.143)$ & $(0.146)$ & & \\
\hline AVERAGE & & & & & $0.001^{* * *}$ & & & & & 0 & 0 & & \\
\hline ALTITUDE & & & & & $(0)$ & & & & & $(0.001)$ & $(0.001)$ & & \\
\hline COEF. VAR. & & & & & & $-1.039 * * *$ & & & & 0.054 & 0.098 & & \\
\hline ALTITUDE & & & & & & & & & & $(0.399)$ & $(0.396)$ & & \\
\hline \multirow{2}{*}{ ISLAND $==1$} & & & & & & & $-0.943^{* * *}$ & & & 0.491 & 0.515 & & \\
\hline & & & & & & & $(0.248)$ & & & $(0.549)$ & $(0.388)$ & & \\
\hline \multirow{2}{*}{$\mathrm{COAST}==1$} & & & & & & & & $-0.769^{* * *}$ & & -0.168 & -0.162 & & \\
\hline & & & & & & & & $(0.179)$ & & $(0.211)$ & $(0.231)$ & & \\
\hline LN DIST. TO & & & & & & & & & $-0.658 * * *$ & $-0.172^{*}$ & $-0.186^{* *}$ & & $-0.186^{* *}$ \\
\hline MADRID & & & & & & & & & $(0.123)$ & $(0.097)$ & $(0.084)$ & & $(0.07)$ \\
\hline $\mathrm{R} 2$ & 0.59 & 0.3 & 0.07 & 0 & 0.24 & 0.24 & 0.09 & 0.27 & 0.29 & 0.63 & 0.63 & 0.59 & 0.59 \\
\hline Obs & 50 & 50 & 50 & 50 & 50 & 50 & 50 & 50 & 49 & 50 & 50 & 50 & 48 \\
\hline
\end{tabular}

Notes: Variables' definitions and sources are available in Table A1. An intercept is included but not reported. Robust standard errors are in parenthesis. *, ** and $* * *$ denote statistical significance at the 10,5 and $1 \%$.

Table 2

Depedent variable: Log of accumulated cases of COVID19/100000 inhab. on April 1, 2020

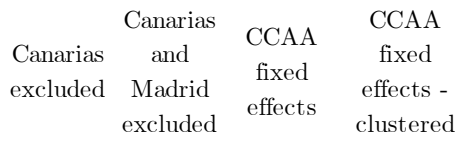

\begin{tabular}{|c|c|c|c|c|c|c|c|c|c|c|c|c|c|}
\hline & 1 & 2 & 3 & 4 & 5 & 6 & 7 & 8 & 9 & 10 & 11 & 12 & 13 \\
\hline $\begin{array}{l}\text { MEAN TEMPERAT. } \\
\text { FEB-MAR } 20\end{array}$ & $\begin{array}{c}-0.236^{* * *} \\
(0.029)\end{array}$ & $\begin{array}{c}-0.256^{* * *} \\
(0.047)\end{array}$ & $\begin{array}{c}-0.235^{* * *} \\
(0.031)\end{array}$ & $\begin{array}{c}-0.237^{* * *} \\
(0.029)\end{array}$ & $\begin{array}{c}-0.235^{* * *} \\
(0.034)\end{array}$ & $\begin{array}{c}-0.23^{* * *} \\
(0.032)\end{array}$ & $\begin{array}{c}-0.246^{* * *} \\
(0.033)\end{array}$ & $\begin{array}{c}-0.224^{* * *} \\
(0.03)\end{array}$ & $\begin{array}{c}-0.211^{* * *} \\
(0.035)\end{array}$ & $\begin{array}{c}-0.256^{* * *} \\
(0.034)\end{array}$ & $\begin{array}{c}-0.25^{* * *} \\
(0.034)\end{array}$ & $\begin{array}{c}-0.194^{* *} \\
(0.094)\end{array}$ & $\begin{array}{c}-0.194^{* *} \\
(0.085)\end{array}$ \\
\hline LATITUDE & & $\begin{array}{c}-0.02 \\
(0.031)\end{array}$ & & & & & & & & & & & \\
\hline LONGITUDE & & & $\begin{array}{l}0.004 \\
(0.02)\end{array}$ & & & & & & & & & & \\
\hline MEAN PRECIP. FEB- & & & & 0.036 & & & & & & & & & \\
\hline MAR 20 & & & & $(0.076)$ & & & & & & & & & \\
\hline AVERAGE & & & & & 0 & & & & & & & & \\
\hline ALTITUDE & & & & & $(0)$ & & & & & & & & \\
\hline COEF. VAR. & & & & & & -0.072 & & & & & & & \\
\hline ALTITUDE & & & & & & $(0.189)$ & & & & & & & \\
\hline ISLAND $==1$ & & & & & & & $\begin{array}{l}0.208 \\
(0.27)\end{array}$ & & & & & & \\
\hline $\mathrm{COAST}==1$ & & & & & & & & $\begin{array}{l}-0.096 \\
(0.136)\end{array}$ & & & & & \\
\hline LN DIST. TO & & & & & & & & & -0.135 & & & & \\
\hline MADRID & & & & & & & & & $(0.093)$ & & & & \\
\hline $\mathrm{R} 2$ & 0.59 & 0.6 & 0.59 & 0.6 & 0.59 & 0.59 & 0.6 & 0.6 & 0.61 & 0.57 & 0.57 & 0.75 & 0.75 \\
\hline Obs & 50 & 50 & 50 & 50 & 50 & 50 & 50 & 50 & 50 & 48 & 47 & 50 & 50 \\
\hline
\end{tabular}

Notes: Variables' definitions and sources are available in Table A1. Robust standard errors are in parenthesis, except in column 13, which reports standard errors clustered at the autonomous community level. An intercept is included but not reported. *, ** and ${ }^{* * *}$ denote statistical significance at the 10,5 and $1 \%$. 
Table 3

Depedent variable: Log of accumulated cases of COVID19/100000 inhab. on April 1, 2020

Madrid Canarias Canarias Canas

excluded excluded and Madrid and Madrid

\begin{tabular}{|c|c|c|c|c|c|}
\hline & & $\begin{array}{c}\text { Madrid } \\
\text { excluded }\end{array}$ & $\begin{array}{l}\text { Canarias } \\
\text { excluded }\end{array}$ & $\begin{array}{c}\text { and Madrid } \\
\text { excluded }\end{array}$ & $\begin{array}{l}\text { and Madrid } \\
\text { excluded }\end{array}$ \\
\hline & 1 & 2 & 3 & 4 & 5 \\
\hline LN DIST. TO MADRID & $\begin{array}{c}-0.514^{* * *} \\
(0.104)\end{array}$ & $\begin{array}{c}-0.658^{* * *} \\
(0.123)\end{array}$ & $\begin{array}{c}-0.497^{* * *} \\
(0.122)\end{array}$ & $\begin{array}{c}-0.709^{* * *} \\
(0.178)\end{array}$ & $\begin{array}{l}-0.087 \\
(0.145)\end{array}$ \\
\hline MEAN TEMPERAT. & & & & & $-0.239^{* * *}$ \\
\hline FEB-MAR 20 & & & & & $(0.039)$ \\
\hline $\mathrm{R} 2$ & 0.3 & 0.29 & 0.24 & 0.23 & 0.57 \\
\hline Obs & 50 & 49 & 48 & 47 & 47 \\
\hline
\end{tabular}

Notes: Variables' definitions and sources are available in Table A1. An intercept is included but not reported. Robust standard errors are in parenthesis. ${ }^{*},{ }^{* *}$ and ${ }^{* * *}$ denote statistical significance at the 10,5 and $1 \%$. 
Table 4

Depedent variable: Log of accumulated cases of COVID19/100000 inhab. on April 1, 2020

\begin{tabular}{|c|c|c|c|c|c|c|c|c|c|c|c|c|}
\hline & 1 & 2 & 3 & 4 & 5 & 6 & 7 & 8 & 9 & 10 & 11 & 12 \\
\hline LOG POPUL. 2019 & $\begin{array}{l}-0.246 \\
(0.159)\end{array}$ & & & & & & & & & & & \\
\hline LOG POP. & & -0.145 & & & & & & & & & & \\
\hline DENSITY. 2019 & & $(0.104)$ & & & & & & & & & & \\
\hline LOG GDP pc 2017 & & & $\begin{array}{c}1.702^{* * *} \\
(0.419)\end{array}$ & & & & & & & & & \\
\hline POP. CONCENTR. & & & & $0.021^{* * *}$ & & & & & & & & \\
\hline 2019 & & & & $(0.006)$ & & & & & & & & \\
\hline AVERAGE PM & & & & & -0.042 & & & & & & & \\
\hline $2.5 \mu \mathrm{m}$ & & & & & $(0.026)$ & & & & & & & \\
\hline AVERAGE PM & & & & & & $-0.048^{* *}$ & & & & & & \\
\hline $10 \mu \mathrm{m}$ & & & & & & $(0.021)$ & & & & & & \\
\hline POPUL.> $64(\%)$ & & & & & & & $\begin{array}{c}0.068^{* *} \\
(0.026)\end{array}$ & & & & & \\
\hline AGRIC. EMPL. (\%) & & & & & & & & $-0.037^{*}$ & & & & \\
\hline 2017 & & & & & & & & $(0.02)$ & & & & \\
\hline INDUST. EMPL. & & & & & & & & & $0.064^{* * *}$ & & & \\
\hline (\%) 2017 & & & & & & & & & $(0.018)$ & & & \\
\hline COMM. REST. & & & & & & & & & & $0.075^{* * *}$ & & \\
\hline HOTELS (\%) & & & & & & & & & & $(0.016)$ & & \\
\hline LOG PASSANGERS & & & & & & & & & & & $-0.031^{*}$ & \\
\hline Feb-Mar & & & & & & & & & & & $(0.018)$ & \\
\hline LOG PASSANG./POP & . Feb-Ma & & & & & & & & & & & $\begin{array}{c}-0.631^{* *} \\
(0.291)\end{array}$ \\
\hline $\mathrm{R} 2$ & 0.09 & 0.05 & 0.21 & 0.11 & 0.05 & 0.1 & 0.14 & 0.07 & 0.21 & 0.21 & 0.06 & 0.07 \\
\hline Obs & 50 & 50 & 50 & 50 & 45 & 50 & 50 & 50 & 50 & 50 & 50 & 50 \\
\hline
\end{tabular}

Notes: Variables' definitions and sources are available in Table A1. An intercept is included but not reported. Robust standard errors are in parenthesis. ${ }^{*},{ }^{* *}$ and ${ }^{* * *}$ denote statistical significance at the 10,5 and $1 \%$. 


\section{Table 5}

Depedent variable: Log of accumulated cases of COVID19/100000 inhab. on April 1, 2020

$$
\begin{array}{cc}
\text { Stepwise } \quad+\text { Temp. } \quad+\text { Temp. - } \\
\text { Stepwise }
\end{array}
$$

\begin{tabular}{|c|c|c|c|c|}
\hline & 1 & 2 & 3 & 4 \\
\hline \multirow[t]{2}{*}{ LOG POPUL. 2019} & 0.042 & & 0.045 & \\
\hline & $(0.265)$ & & $(0.199)$ & \\
\hline LOG POP. DENSITY. & -0.048 & & $0.271^{*}$ & $0.212^{* * *}$ \\
\hline 2019 & $(0.21)$ & & $(0.141)$ & $(0.067)$ \\
\hline \multirow[t]{2}{*}{ LOG GDP pc 2017} & $1.528^{* *}$ & $1.455^{* * *}$ & -0.338 & \\
\hline & $(0.666)$ & $(0.424)$ & $(0.423)$ & \\
\hline POP. CONCENTR. & 0.006 & & 0.001 & \\
\hline 2019 & $(0.008)$ & & $(0.006)$ & \\
\hline \multirow[t]{2}{*}{ 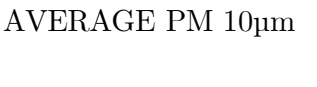 } & 0.004 & & 0.001 & \\
\hline & $(0.023)$ & & $(0.018)$ & \\
\hline \multirow[t]{2}{*}{ POPUL.> $64(\%)$} & 0.037 & $0.04^{*}$ & -0.025 & \\
\hline & $(0.027)$ & $(0.024)$ & $(0.02)$ & \\
\hline \multicolumn{5}{|l|}{ AGRIC. EMPL. (\%) } \\
\hline \multicolumn{5}{|l|}{2017} \\
\hline INDUST. EMPL. (\%) & 0 & & 0.005 & \\
\hline 2017 & $(0.037)$ & & $(0.02)$ & \\
\hline COMM. REST. & -0.037 & $-0.051^{* * *}$ & 0.01 & \\
\hline HOTELS (\%) & $(0.035)$ & $(0.017)$ & $(0.024)$ & \\
\hline LOG PASSANGERS & -0.014 & & -0.019 & \\
\hline Feb-Mar & $(0.034)$ & & $(0.021)$ & \\
\hline MEAN TEMPERAT. & & & $-0.345^{* * *}$ & $-0.295^{* * *}$ \\
\hline FEB-MAR 20 & & & $(0.053)$ & $(0.03)$ \\
\hline $\mathrm{R} 2$ & 0.42 & 0.41 & 0.69 & 0.67 \\
\hline Obs & 50 & 50 & 50 & 50 \\
\hline
\end{tabular}

Notes: Variables' definitions and sources are available in Table A1. An intercept is included but not reported. Robust standard errors are in parenthesis. ${ }^{*}, * *$ and ${ }^{* * *}$ denote statistical significance at the 10,5 and $1 \%$. 


\begin{tabular}{|c|c|c|c|c|c|c|c|c|c|c|c|c|c|}
\hline & 1 & 2 & 3 & 4 & 5 & 6 & 7 & 8 & 9 & 10 & 11 & $\begin{array}{c}\text { Step- } \\
\text { wise } \\
12\end{array}$ & $\begin{array}{c}\text { Step-wise } \\
\text { w/o } \\
\text { Canarias } \\
13\end{array}$ \\
\hline MEAN TEMPERAT. & $-0.153^{* * *}$ & & & & & & & & & -0.141 & -0.101 & & \\
\hline FEB 1- MAR 15. 20 & $(0.056)$ & & & & & & & & & $(0.27)$ & $(0.11)$ & & \\
\hline LATITUDE & & $\begin{array}{c}0.081^{* *} \\
(0.037)\end{array}$ & & & & & & & & $\begin{array}{l}-0.112 \\
(0.194)\end{array}$ & & & \\
\hline LONGITUDE & & & $\begin{array}{l}0.047^{*} \\
(0.028)\end{array}$ & & & & & & & $\begin{array}{c}0.069 \\
(0.063)\end{array}$ & & & \\
\hline $\begin{array}{l}\text { MEAN PRECIP. FEB } \\
\text { 1- MAR 15. } 20\end{array}$ & & & & $\begin{array}{c}0.055 \\
(0.097)\end{array}$ & & & & & & $\begin{array}{c}0.236 \\
(0.234)\end{array}$ & $\begin{array}{c}0.038 \\
(0.144)\end{array}$ & & \\
\hline AVERAGE & & & & & $0.001^{* *}$ & & & & & -0.001 & 0 & & \\
\hline ALTITUDE & & & & & $(0)$ & & & & & $(0.001)$ & $(0.001)$ & & \\
\hline $\begin{array}{l}\text { COEF. VAR. } \\
\text { ALTITUDE }\end{array}$ & & & & & & $-0.793^{* *}$ & & & & $\begin{array}{l}-0.027 \\
(0.785)\end{array}$ & $\begin{array}{c}0.099 \\
(0.798)\end{array}$ & & \\
\hline ISLAND $==1$ & & & & & & & $\begin{array}{l}-0.494^{*} \\
(0.253)\end{array}$ & & & $\begin{array}{c}0.638 \\
(0.984)\end{array}$ & $\begin{array}{c}0.828 \\
(0.576)\end{array}$ & & \\
\hline $\mathrm{COAST}==1$ & & & & & & & & $\begin{array}{c}-0.621^{* *} \\
(0.254)\end{array}$ & & $\begin{array}{l}-0.333 \\
(0.456)\end{array}$ & $\begin{array}{l}-0.244 \\
(0.429)\end{array}$ & & \\
\hline $\begin{array}{l}\text { LN DIST. TO } \\
\text { MADRID }\end{array}$ & & & & & & & & & $\begin{array}{c}-0.468^{* * *} \\
(0.163)\end{array}$ & $\begin{array}{c}-0.502^{* *} \\
(0.198)\end{array}$ & $\begin{array}{c}-0.52^{* * *} \\
(0.173)\end{array}$ & $\begin{array}{c}-0.542^{* * *} \\
(0.105)\end{array}$ & $\begin{array}{c}-0.627 * * * \\
(0.104)\end{array}$ \\
\hline $\mathrm{R} 2$ & 0.15 & 0.07 & 0.03 & 0.00 & 0.06 & 0.08 & 0.01 & 0.10 & 0.09 & 0.27 & 0.25 & 0.19 & 0.20 \\
\hline Obs & 50 & 50 & 50 & 50 & 50 & 50 & 50 & 50 & 49 & 50 & 50 & 50 & 48 \\
\hline
\end{tabular}

Notes: Variables' definitions and sources are available in Table A1. Robust standard errors are in parenthesis.

Table 7

Depedent variable: Log of accumulated cases of COVID19/100000 inhab. on March 15, 2020

$\begin{array}{cccc} & \text { Canarias } & \text { CCAA } & \text { CCAA } \\ \text { Canarias } & \text { and } & \text { fixed effects } \\ \text { excluded } & \text { Madrid } & \text { fixed } & \text { - clustered } \\ & \text { excluded } & \text { effects } & \text { SEs }\end{array}$

\begin{tabular}{|c|c|c|c|c|c|c|c|c|c|c|c|c|c|}
\hline & 1 & 2 & 3 & 4 & 5 & 6 & 7 & 8 & 9 & 10 & 11 & 12 & 13 \\
\hline MEAN TEMPERAT. & $-0.153^{* * *}$ & $-0.192 * *$ & $-0.145^{* *}$ & $-0.16^{* * *}$ & $-0.144^{* *}$ & $-0.133^{* *}$ & $-0.167^{* *}$ & $-0.12^{* *}$ & -0.081 & $-0.18^{* *}$ & $-0.167^{* *}$ & -0.162 & -0.162 \\
\hline FEB 1- MAR 15. 20 & $(0.056)$ & $(0.089)$ & $(0.058)$ & $(0.059)$ & $(0.067)$ & $(0.059)$ & $(0.066)$ & $(0.058)$ & $(0.075)$ & $(0.07)$ & $(0.07)$ & $(0.216)$ & $(0.233)$ \\
\hline LATITUDE & & $\begin{array}{l}-0.038 \\
(0.049)\end{array}$ & & & & & & & & & & & \\
\hline \multirow{2}{*}{ LONGITUDE } & & & 0.018 & & & & & & & & & & \\
\hline & & & $(0.032)$ & & & & & & & & & & \\
\hline MEAN PRECIP. FEB & & & & -0.054 & & & & & & & & & \\
\hline 1- MAR 15. 20 & & & & $(0.084)$ & & & & & & & & & \\
\hline AVERAGE & & & & & 0 & & & & & & & & \\
\hline ALTITUDE & & & & & $(0)$ & & & & & & & & \\
\hline COEF. VAR. & & & & & & -0.247 & & & & & & & \\
\hline ALTITUDE & & & & & & $(0.281)$ & & & & & & & \\
\hline ISL $A \mathrm{ND}--1$ & & & & & & & 0.298 & & & & & & \\
\hline 1SLAND $=1$ & & & & & & & $(0.406)$ & & & & & & \\
\hline$C O \triangle \mathrm{ST}_{-}-1$ & & & & & & & & -0.262 & & & & & \\
\hline COAN & & & & & & & & $(0.239)$ & & & & & \\
\hline LN DIST. TO & & & & & & & & & $-0.4^{* *}$ & & & & \\
\hline MADRID & & & & & & & & & $(0.185)$ & & & & \\
\hline $\mathrm{R} 2$ & 0.15 & 0.15 & 0.15 & 0.15 & 0.15 & 0.15 & 0.15 & 0.16 & 0.22 & 0.15 & 0.14 & 0.57 & 0.57 \\
\hline Obs & 50 & 50 & 50 & 50 & 50 & 50 & 50 & 50 & 50 & 48 & 47 & 50 & 50 \\
\hline
\end{tabular}

Notes: Variables' definitions and sources are available in Table A1. Robust standard errors are in parenthesis, except in column 13, which reports standard errors clustered at the autonomous community level. 
Table 8

Depedent variable: Log of accumulated cases of COVID19/100000 inhab. on March 15, 2020

\begin{tabular}{lccccc} 
& & $\begin{array}{c}\text { Madrid } \\
\text { excluded }\end{array}$ & $\begin{array}{c}\text { Canarias } \\
\text { excluded }\end{array}$ & $\begin{array}{c}\text { Canarias and Canarias and } \\
\text { Madrid } \\
\text { excluded }\end{array}$ & $\begin{array}{c}\text { Madrid } \\
\text { excluded }\end{array}$ \\
& 1 & 2 & 3 & 4 & 5 \\
\hline LN DIST. TO MADRID & $-0.542^{* * *}$ & $-0.468^{* * *}$ & $-0.627^{* * *}$ & $-0.609^{* * *}$ & -0.293 \\
MEAN TEMPERAT. & $(0.105)$ & $(0.163)$ & $(0.104)$ & $(0.225)$ & $(0.293)$ \\
FEB 1- MAR 15. 20 & & & & & -0.133 \\
R2 & 0.19 & 0.09 & 0.2 & 0.09 & 0.16 \\
Obs & 50 & 49 & 48 & 47 & 47 \\
\hline
\end{tabular}

Notes: Variables' definitions and sources are available in Table A1. Robust standard errors are in parenthesis.

Table 9

Depedent variable: Log of accumulated cases of COVID19/100000 inhab. on March 15, 2020

\begin{tabular}{|c|c|c|c|c|c|c|c|c|c|c|c|c|}
\hline & 1 & 2 & 3 & 4 & 5 & 6 & 7 & 8 & 9 & 10 & 11 & 12 \\
\hline LOG POPUL. 2019 & $\begin{array}{c}0.12 \\
(0.173)\end{array}$ & & & & & & & & & & & \\
\hline LOG POP. & & 0.116 & & & & & & & & & & \\
\hline DENSITY. 2019 & & $(0.12)$ & & & & & & & & & & \\
\hline LOG GDP pc 2017 & & & $\begin{array}{c}1.863^{* *} \\
(0.794)\end{array}$ & & & & & & & & & \\
\hline POP. CONCENTR. & & & & $0.028^{* * *}$ & & & & & & & & \\
\hline 2019 & & & & $(0.01)$ & & & & & & & & \\
\hline AVERAGE PM & & & & & -0.044 & & & & & & & \\
\hline $2.5 \mu \mathrm{m}$ & & & & & $(0.042)$ & & & & & & & \\
\hline AVERAGE PM & & & & & & 0.004 & & & & & & \\
\hline $10 \mu \mathrm{m}$ & & & & & & $(0.029)$ & & & & & & \\
\hline POPUL.> $64(\%)$ & & & & & & & $\begin{array}{l}-0.007 \\
(0.03)\end{array}$ & & & & & \\
\hline AGRIC. EMPL. & & & & & & & & $-0.083^{* * *}$ & & & & \\
\hline (\%) 2017 & & & & & & & & $(0.023)$ & & & & \\
\hline INDUST. EMPL. & & & & & & & & & $0.06^{*}$ & & & \\
\hline (\%) 2017 & & & & & & & & & $(0.032)$ & & & \\
\hline COMM. REST. & & & & & & & & & & -0.041 & & \\
\hline HOTELS (\%) & & & & & & & & & & $(0.03)$ & & \\
\hline LOG & & & & & & & & & & & 0.024 & \\
\hline PASSANGERS Feb- & & & & & & & & & & & $(0.022)$ & \\
\hline LOG PASS./POP. & & & & & & & & & & & & 0.092 \\
\hline Feb-Mar & & & & & & & & & & & & $(0.424)$ \\
\hline $\mathrm{R} 2$ & 0.01 & 0.02 & 0.14 & 0.11 & 0.02 & 0 & 0 & 0.21 & 0.11 & 0.04 & 0.02 & 0 \\
\hline Obs & 50 & 50 & 50 & 50 & 45 & 50 & 50 & 50 & 50 & 50 & 50 & 50 \\
\hline
\end{tabular}

Notes: Variables' definitions and sources are available in Table A1. Robust standard errors are in parenthesis. 
Depedent variable: Log of accumulated cases of COVID19/100000 inhab. March 15, 2020

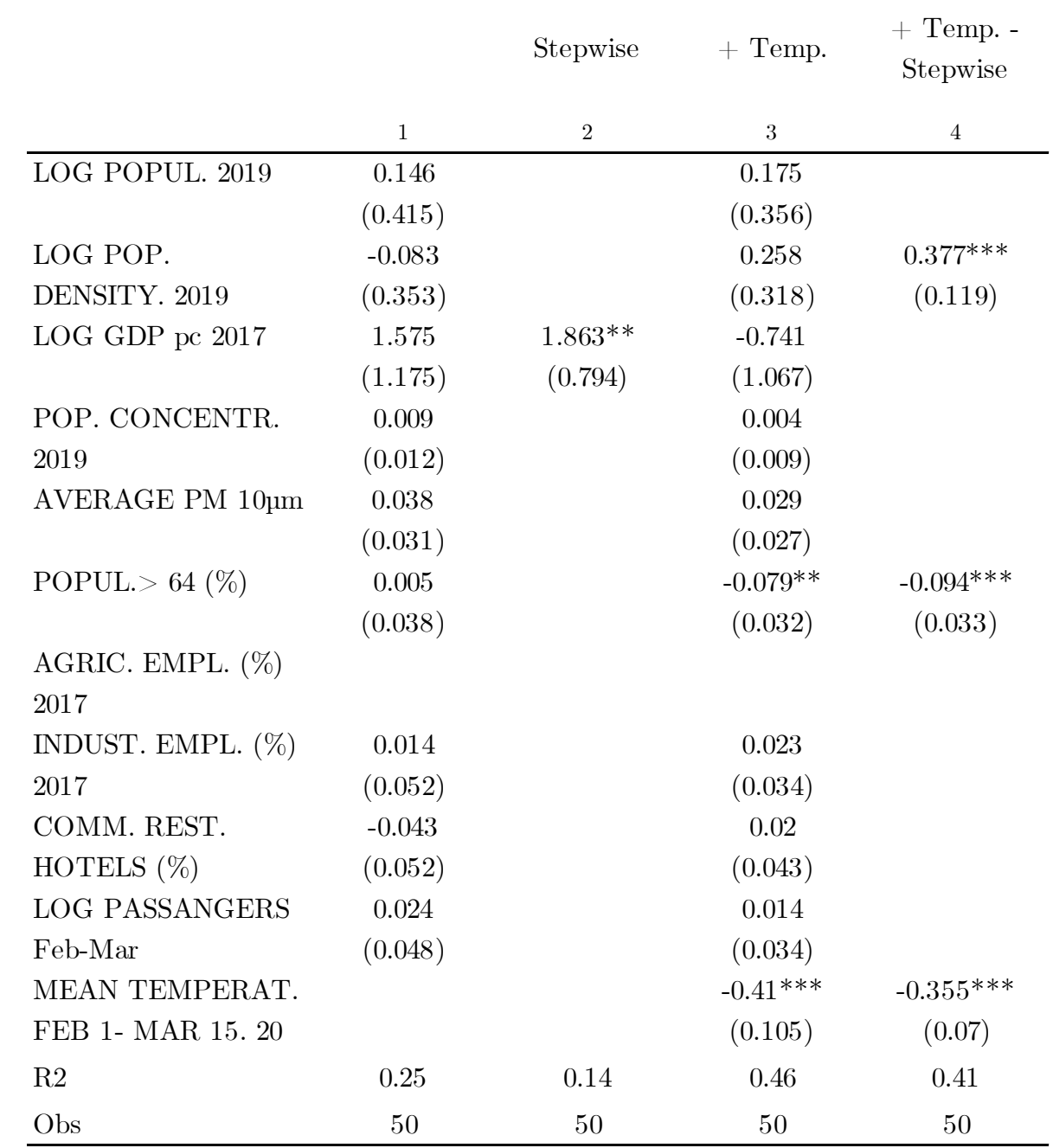

Notes: Variables' definitions and sources are available in Table A1. Robust standard errors are in parenthesis. 
Tabla 11 - Changes in COVID-19 cases

Dependent variable: difference in the rate of accumulated cases of COVID-19 between two dates

Panel A: Temperature without lags

Difference Difference Difference Difference

between May 1 between April between April between May 1 and April $1 \quad 1$ and March 1515 and April 1 and April 15

\begin{tabular}{lcccc} 
& 1 & 2 & 3 & 4 \\
\hline Log. accumulated case rate at the beginning of & -0.126 & $-0.65^{* * *}$ & -0.042 & -0.017 \\
the period & $(0.076)$ & $(0.049)$ & $(0.059)$ & $(0.029)$ \\
Average temperature during the indicated & $-0.136^{* * *}$ & $-0.179^{* * *}$ & $-0.062^{* *}$ & $-0.041^{* * *}$ \\
period & $(0.032)$ & $(0.026)$ & $(0.024)$ & $(0.012)$ \\
$\mathrm{R}^{2}$ & 0.47 & 0.76 & 0.26 & 0.25 \\
$\mathrm{~N}$ & 46 & 50 & 46 & 46 \\
\hline
\end{tabular}

Log. accumulated case rate at the beginning of

the period

Difference between mean temperature in the indicated period and that of the previous period

$\mathrm{R}^{2}$

Log. accumulated case rate at the beginning of

the period

Difference between mean temperature in the

indicated period and that in the previous period

Mean temperature in the previous period

0.073

$(0.062)$

$\mathrm{R}^{2}$

Notes: The dependent variable is the difference in the log. of accumulated cases of COVID-19 per 100,000 infwb

temperature in the indicated period and that of the previous period" refers, in column 5, to the difference in average temperature between April and March; in column 6 , the difference between the secoul a

fortnight of March, etc. The variable "mean temperature in the previous period" refers, in column 9, to the average of March; in column 10, of the first fortnight of March, etc. In Panel B, all temperature

variables are calculated with a 10-day lag (for example, when temperature refers to the month of April, it is actually calculated for the period from March 20 to April 20). Robust standard errors appear in parentheses. $*, * *, * *$ indicates that the coefficient is statistically significant at 10,5 and $1 \%$, respectively.
Panel B: Temperature lagged 10 days

Difference Difference

tween May 1 between April between April between May 1 and March 1515 and April 1 and April 15

\begin{tabular}{cccc}
1 & 2 & 3 & 4 \\
\hline$-0.135^{*}$ & $-0.633^{* * *}$ & -0.04 & $-0.066^{* *}$ \\
$(0.077)$ & $(0.051)$ & $(0.055)$ & $(0.031)$ \\
$-0.137^{* * *}$ & $-0.189^{* * *}$ & $-0.048^{* * *}$ & $-0.073^{* * *}$ \\
$(0.031)$ & $(0.028)$ & $(0.017)$ & $(0.014)$ \\
0.48 & 0.75 & 0.25 & 0.39 \\
46 & 50 & 46 & 46 \\
\hline & & & \\
5 & 6 & 7 & 8 \\
\hline $0.105^{*}$ & $-0.458^{* * *}$ & $0.07^{* *}$ & $0.047^{*}$ \\
$(0.055)$ & $(0.066)$ & $(0.034)$ & $(0.026)$ \\
0.015 & $0.14^{* *}$ & -0.029 & 0.016 \\
$(0.032)$ & $(0.054)$ & $(0.019)$ & $(0.024)$ \\
0.1 & 0.5 & 0.11 & 0.11 \\
46 & 50 & 46 & 46 \\
\hline \multicolumn{4}{c}{} \\
9 & 10 & 11 & 12 \\
\hline$-0.143^{*}$ & $-0.621^{* * *}$ & -0.041 & $-0.067^{*}$ \\
$(0.083)$ & $(0.048)$ & $(0.065)$ & $(0.033)$ \\
$-0.124^{* * *}$ & $-0.092^{*}$ & $-0.047^{* *}$ & $-0.069^{* * *}$ \\
$(0.038)$ & $(0.051)$ & $(0.017)$ & $(0.025)$ \\
$-0.137^{* * *}$ & $-0.179^{* * *}$ & $-0.049^{* *}$ & $-0.073^{* * *}$ \\
$(0.032)$ & $(0.027)$ & $(0.021)$ & $(0.014)$ \\
0.49 & 0.77 & 0.25 & 0.4 \\
46 & 50 & 46 & 46 \\
\hline
\end{tabular}

and first 
Table A1: Description of variables and sources

\begin{tabular}{|c|c|c|}
\hline Variable name & Description & Source \\
\hline CASES COVID-19 & $\begin{array}{l}\text { Accumulated confirmed cases of COVID-19 over } 100,000 \\
\text { inhabitants. }\end{array}$ & $\begin{array}{l}\text { Escovid19data at } \\
\text { https://github.com/montera34/escovi } \\
\text { d19data }\end{array}$ \\
\hline DEATHS COVID-19 & $\begin{array}{l}\text { Accumulated confirmed deaths related to COVID-19 over } \\
100,000 \text { inhabitants. }\end{array}$ & $\begin{array}{l}\text { Escovid19data at } \\
\text { https://github.com/montera34/escovi } \\
\text { d19data }\end{array}$ \\
\hline MEAN TEMPERATURE & $\begin{array}{l}\text { Average of daily mean temperatures during the specified } \\
\text { period. Daily mean temperatures are the average between } \\
\text { the maximim and minimum temperatures of each day. } \\
\text { Provincial values are calculated as the weighted average of } \\
\text { available weather stations where weights are the population } \\
\text { of the municipality in which a station is located. } \\
\text { When lags are included, the variable is constructed with a } \\
\text { 10-day lag (for example, when temperature refers to the } \\
\text { month of April, it is actually calculated for the period from } \\
\text { March } 20 \text { to April 20). }\end{array}$ & $\begin{array}{l}\text { Own elaboration using data from } \\
\text { datosclima.es -Base de datos } \\
\text { Meteorológica. }\end{array}$ \\
\hline MEAN PRECIPITATION & $\begin{array}{l}\text { Average of daily precipitations during the specified period. } \\
\text { Provincial values are calculated as the weighted average of } \\
\text { available weather stations where weights are the population } \\
\text { of the municipality in which a station is located. }\end{array}$ & $\begin{array}{l}\text { Own elaboration using data from } \\
\text { datosclima.es -Base de datos } \\
\text { Meteorológica. }\end{array}$ \\
\hline LATITUDE & Latitude of the centroid of the province. & Own elaboration using GIS. \\
\hline LONGITUDE & Latitude of the centroid of the province. & Own elaboration using GIS. \\
\hline AVERAGE ALTITUDE & $\begin{array}{l}\text { Average altitude of the province (unweighted average of the } \\
\text { municipalities of the province). }\end{array}$ & $\begin{array}{l}\text { Own elaboration using data from } \\
\text { Nomenclátor Geográfico de } \\
\text { Municipios y Entidades de Población } \\
\text { (Instituto Geográfico Nacional). }\end{array}$ \\
\hline COEF. VAR. ALTITUDE & $\begin{array}{l}\text { Coefficient of variation of the altitude of the municipalities } \\
\text { of the province. }\end{array}$ & $\begin{array}{l}\text { Own elaboration using data from } \\
\text { Nomenclátor Geográfico de } \\
\text { Municipios y Entidades de Población } \\
\text { (Instituto Geográfico Nacional). }\end{array}$ \\
\hline ISLAND $==1$ & Dummy variable equal to 1 if the province is an island. & Own elaboration. \\
\hline $\mathrm{COAST}==1$ & Dummy variable equal to 1 if the province is coastal. & Own elaboration. \\
\hline LN DIST. TO MADRID & $\begin{array}{l}\text { Natural logarithm of the linear distance between the } \\
\text { centroid of the province and Madrid (in } 100 \mathrm{~km} \text { ). }\end{array}$ & Own elaboration using GIS. \\
\hline PROVINCE NAME & Name of the province. & \\
\hline AUT. COMMUNITY NAME & Name of the autonomous community. & \\
\hline LOG POPUL. 2019 & Natural logarithm of the total population in 2019 & $\begin{array}{l}\text { Padrón Municipal. Instituto Nacional } \\
\text { de Estadística. }\end{array}$ \\
\hline LOG POP. DENSITY. 2019 & $\begin{array}{l}\text { Natural logarithm of the total population in } 2019 \text { divided by } \\
\text { surface area. }\end{array}$ & $\begin{array}{l}\text { Own elaboration using data from } \\
\text { Padrón Municipal (Instituto Nacional }\end{array}$ \\
\hline LOG GDP pc 2017 & Natural logarithm of GDP per capita in 2017. & $\begin{array}{l}\text { Contabilidad Regional de España } \\
\text { (Instituto Nacional de Estadística). }\end{array}$ \\
\hline
\end{tabular}




\begin{tabular}{lll}
\hline POP. CONCENTR. 2019 & Percentage of the population living in the most populated & Own elaboration using data from \\
& $\begin{array}{l}\text { 10\% of the territory. It is calculated using municipalities' } \\
\text { population and surface area. }\end{array}$ & $\begin{array}{l}\text { Padrón Municipal (Instituto Nacional } \\
\text { de Estadística). }\end{array}$
\end{tabular}

POP DENSITY IN 10\% Natural logarithm of population density corresponding to the Own elaboration using data from MOST POPULATED most populated $10 \%$ of the territory. It is calculated using municipalities' population and surface area. Padrón Municipal (Instituto Nacional de Estadística).

AVERAGE PM 2.5um

Anual average in 2018 of particles lower than $2.5 \mu \mathrm{m}$.

Own elaboration using data from Provincial values are calculated as the weighted average of Estaciones de calidad del aire. available air quality stations where weights are the Infraestructura de Datos Espaciales population of the municipality in which a station is located. (Ministerio para la Transición Ecológica y el Reto Demográfico).

AVERAGE PM 10um

POPUL. $>64(\%)$

AGRIC. EMPL. (\%) 2017

INDUST. EMPL. (\%) 2017

CONST. EMPL. (\%) 2017

COMM. REST. HOTELS EMP (\%)

PROF. SERVICES (\%) 2017

PUBLIC ADMON. EMPL (\%) 2017

LOG PASSANG./POP. Feb- One plus the natural logarithm of airline passengers over Mar total population during February and March of 2020.

LOG PASSANGERS FebMar
Anual average in 2018 of particles lower than $2.5 \mu \mathrm{m}$. Provincial values are calculated as the weighted average of available air quality stations where weights are the population of the municipality in which a station is located.

Percentage of population older than 64 years.

Percentage of workers in the agricultural sector in 2017 $(\mathrm{NACE}=\mathrm{A})$

Percentage of workers in the agricultural sector in 2017 $(\mathrm{NACE}=\mathrm{B}-\mathrm{E})$.

Percentage of workers in the construction sector in 2017 $(\mathrm{NACE}=\mathrm{F})$

Percentage of workers in commerce, restaurants and hotels in $2017(\mathrm{NACE}=\mathrm{G}-\mathrm{J})$

Percentage of workers in professional services in 2017 $(\mathrm{NACE}=\mathrm{K}-\mathrm{N})$.
Own elaboration using data from Estaciones de calidad del aire. Infraestructura de Datos Espaciales (Ministerio para la Transición Ecológica y el Reto Demográfico).

Own elaboration using data from Padrón Municipal (Instituto Nacional de Estadística).

Contabilidad Regional de España (Instituto Nacional de Estadística).

Contabilidad Regional de España (Instituto Nacional de Estadística).

Contabilidad Regional de España (Instituto Nacional de Estadística).

Contabilidad Regional de España (Instituto Nacional de Estadística).

Contabilidad Regional de España (Instituto Nacional de Estadística).

Contabilidad Regional de España (Instituto Nacional de Estadística).

Estadística de tráfico de pasajeros, operaciones y carga en los aeropuertos españoles (AENA)

Estadística de tráfico de pasajeros, operaciones y carga en los aeropuertos españoles (AENA) 
Table A2 - Descriptive statistics

\begin{tabular}{|c|c|c|c|c|c|}
\hline Variable & Obs & Mean & Std. Dev. & Min & Max \\
\hline CASES COVID-19 on March 15 & 50 & 16.695 & 24.627 & 1.150 & 123.360 \\
\hline CASES COVID-19 on April 1 & 50 & 236.358 & 179.390 & 40.460 & 743.490 \\
\hline CASES COVID-19 on April 15 & 46 & 430.834 & 341.554 & 55.690 & 1373.350 \\
\hline CASES COVID-19 on May 1 & 46 & 602.689 & 487.436 & 62.480 & 1960.830 \\
\hline DEATHS COVID-19 on March 15 & 46 & 0.407 & 0.875 & 0.000 & 4.830 \\
\hline DEATHS COVID-19 on April 1 & 50 & 18.147 & 16.640 & 1.150 & 62.660 \\
\hline DEATHS COVID-19 on April 15 & 50 & 39.633 & 32.657 & 2.770 & 132.930 \\
\hline DEATHS COVID-19 on May 1 & 46 & 56.953 & 43.447 & 3.480 & 197.470 \\
\hline MEAN TEMPERATURE JANUARY & 50 & 8.416 & 3.019 & 3.969 & 16.835 \\
\hline MEAN TEMP. FEBRUARY & 50 & 11.972 & 2.503 & 8.175 & 19.290 \\
\hline MEAN TEMP 1 - 15 FEB & 50 & 12.207 & 2.533 & 8.333 & 19.491 \\
\hline MEAN TEMP 16 - 29 FEB & 50 & 11.721 & 2.516 & 8.005 & 19.076 \\
\hline MEAN TEMP MARCH & 50 & 11.921 & 2.354 & 7.888 & 17.639 \\
\hline MEAN TEMP 1- $15 \mathrm{MARCH}$ & 50 & 13.206 & 2.462 & 9.065 & 18.747 \\
\hline MEAN TEMP 16-31 MARCH & 50 & 10.957 & 2.415 & 6.443 & 16.809 \\
\hline MEAN TEMP APRIL & 50 & 14.446 & 1.753 & 11.015 & 18.892 \\
\hline MEAN TEMP 1- 15 APRIL & 50 & 13.903 & 1.763 & 10.762 & 19.291 \\
\hline MEAN TEMP 16-30 APRIL & 50 & 14.989 & 1.923 & 11.113 & 18.492 \\
\hline MEAN TEMP. FEBRUARY - 10 DAYS L & 50 & 11.881 & 2.558 & 7.977 & 19.035 \\
\hline MEAN TEMP 1 - 15 FEB - 10 DAYS LA & 50 & 13.476 & 2.593 & 9.701 & 20.728 \\
\hline MEAN TEMP 16 - 29 FEB - 10 DAYS L $f$ & 50 & 11.382 & 2.573 & 7.439 & 18.506 \\
\hline MEAN TEMP MARCH - 10 DAYS LAG & 50 & 12.733 & 2.277 & 8.840 & 18.114 \\
\hline MEAN TEMP 1- 15 MARCH - 10 DAYS & 50 & 12.716 & 2.716 & 8.234 & 18.639 \\
\hline MEAN TEMP 16-31 MARCH - 10 DAYS & 50 & 12.738 & 2.215 & 8.689 & 17.964 \\
\hline MEAN TEMP APRIL - 10 DAYS LAG & 50 & 14.133 & 1.786 & 10.679 & 19.097 \\
\hline MEAN TEMP 1- 15 APRIL - 10 DAYS L 1 & 50 & 12.006 & 2.241 & 7.835 & 18.776 \\
\hline MEAN TEMP 16-30 APRIL - 10 DAYS L $t$ & 50 & 14.798 & 1.689 & 11.441 & 19.197 \\
\hline MEAN DAILY PRECIPITATION JANUA & 50 & 1.888 & 1.485 & 0.089 & 6.954 \\
\hline MEAN DAILY PREC. FEBRUARY & 50 & 0.342 & 0.655 & 0.001 & 2.846 \\
\hline MEAN DAILY PREC 1 - 15 FEB & 50 & 0.225 & 0.367 & 0.001 & 1.946 \\
\hline MEAN DAILY PREC 16 - 29 FEB & 50 & 0.467 & 0.993 & 0.000 & 4.202 \\
\hline MEAN DAILY PREC MARCH & 50 & 2.419 & 1.037 & 0.783 & 4.853 \\
\hline MEAN DAILY PREC 1- 15 MARCH & 50 & 1.578 & 1.858 & 0.012 & 6.529 \\
\hline MEAN DAILY PREC 16-31 MARCH & 50 & 3.036 & 1.916 & 0.215 & 7.670 \\
\hline MEAN DAILY PREC APRIL & 50 & 2.615 & 1.300 & 0.225 & 7.016 \\
\hline MEAN DAILY PREC 1- 15 APRIL & 50 & 2.641 & 1.213 & 0.094 & 6.061 \\
\hline
\end{tabular}




\begin{tabular}{|c|c|c|c|c|c|}
\hline MEAN DAILY PREC 16-30 APRIL & 50 & 2.579 & 2.066 & 0.000 & 11.337 \\
\hline MEAN DAILY PREC. FEBRUARY - 10 I & 50 & 0.269 & 0.477 & 0.002 & 2.470 \\
\hline MEAN DAILY PREC 1 - 15 FEB - 10 D & 50 & 0.200 & 0.345 & 0.000 & 1.600 \\
\hline MEAN DAILY PREC 16 - 29 FEB - 10 D & 50 & 0.290 & 0.536 & 0.000 & 2.781 \\
\hline MEAN DAILY PREC MARCH - 10 DAY & 50 & 2.368 & 1.457 & 0.297 & 6.798 \\
\hline MEAN DAILY PREC 1- 15 MARCH - 10 & 50 & 3.502 & 4.269 & 0.000 & 15.984 \\
\hline MEAN DAILY PREC 16-31 MARCH - 10 & 50 & 2.035 & 1.184 & 0.204 & 5.488 \\
\hline MEAN DAILY PREC APRIL - 10 DAYS I & 50 & 3.052 & 1.576 & 0.265 & 8.812 \\
\hline MEAN DAILY PREC 1- 15 APRIL - 10 D & 50 & 2.315 & 2.304 & 0.005 & 15.257 \\
\hline MEAN DAILY PREC 16-30 APRIL - 10 D & 50 & 3.260 & 1.908 & 0.076 & 10.756 \\
\hline LATITUDE & 50 & 40.123 & 3.136 & 28.303 & 43.295 \\
\hline LONGITUDE & 50 & -3.823 & 3.694 & -17.023 & 2.908 \\
\hline AVERAGE ALTITUDE & 50 & 534.898 & 276.038 & 111.009 & 1044.142 \\
\hline COEF. VAR. ALTITUDE & 50 & 0.523 & 0.345 & 0.060 & 1.355 \\
\hline ISLAND $==1$ & 50 & 0.060 & 0.240 & 0.000 & 1.000 \\
\hline $\mathrm{COAST}==1$ & 50 & 0.440 & 0.501 & 0.000 & 1.000 \\
\hline LN DIST. TO MADRID & 50 & 12.537 & 0.782 & 8.911 & 14.412 \\
\hline LOG POPUL. 2019 & 50 & 13.312 & 0.901 & 11.392 & 15.712 \\
\hline LOG POP. DENSITY. 2019 & 50 & -0.381 & 1.152 & -2.453 & 2.117 \\
\hline LOG GDP pc 2017 & 50 & 10.042 & 0.198 & 9.754 & 10.517 \\
\hline POP. CONCENTR. 2019 & 50 & 64.732 & 11.843 & 40.616 & 85.402 \\
\hline POP DENSITY IN 10\% MOST POPULA] & 50 & 6.019 & 1.193 & 3.864 & 8.634 \\
\hline AVERAGE PM $2.5 \mu \mathrm{m}$ & 45 & 11.044 & 3.552 & 4.300 & 19.535 \\
\hline AVERAGE PM 10um & 50 & 19.912 & 4.977 & 12.000 & 29.418 \\
\hline POPUL.> $64(\%)$ & 50 & 21.007 & 4.060 & 14.727 & 31.381 \\
\hline AGRIC. EMPL. (\%) 2017 & 50 & 7.119 & 5.335 & 0.129 & 26.076 \\
\hline INDUST. EMPL. (\%) 2017 & 50 & 12.661 & 5.332 & 4.455 & 25.919 \\
\hline CONST. EMPL. (\%) 2017 & 50 & 6.376 & 1.386 & 2.679 & 9.984 \\
\hline COMM. REST. HOTELS EMP (\%) & 50 & 30.751 & 4.514 & 22.804 & 46.237 \\
\hline PROF. SERVICES (\%) 2017 & 50 & 11.917 & 2.996 & 7.098 & 22.820 \\
\hline PUBLIC ADMON. EMPL. (\%) 2017 & 50 & 31.175 & 3.192 & 21.591 & 38.192 \\
\hline LOG PASSANG./POP. Feb-Mar & 50 & 0.167 & 0.316 & 0.000 & 1.367 \\
\hline LOG PASSANGERS Feb-Mar & 50 & 7.257 & 5.790 & 0.000 & 15.667 \\
\hline TOTAL POPULATION 2019 & 50 & 937099 & 1200404 & 88636 & 6663394 \\
\hline GDP 2017 & 50 & 23200000 & 37200000 & 2192878 & 221000000 \\
\hline SURFACE AREA SQ-KM & 50 & 1009341 & 480614 & 190904 & 2176628 \\
\hline
\end{tabular}




\section{Appendix. Results for deaths related to COVID-19}

Table A1

Depedent variable: Log of accumulated deaths related to COVID19/100000 inhab. on April 1, 2020

Step-wise

Step-wise $\quad \mathrm{w} / \mathrm{o}$

Canarias

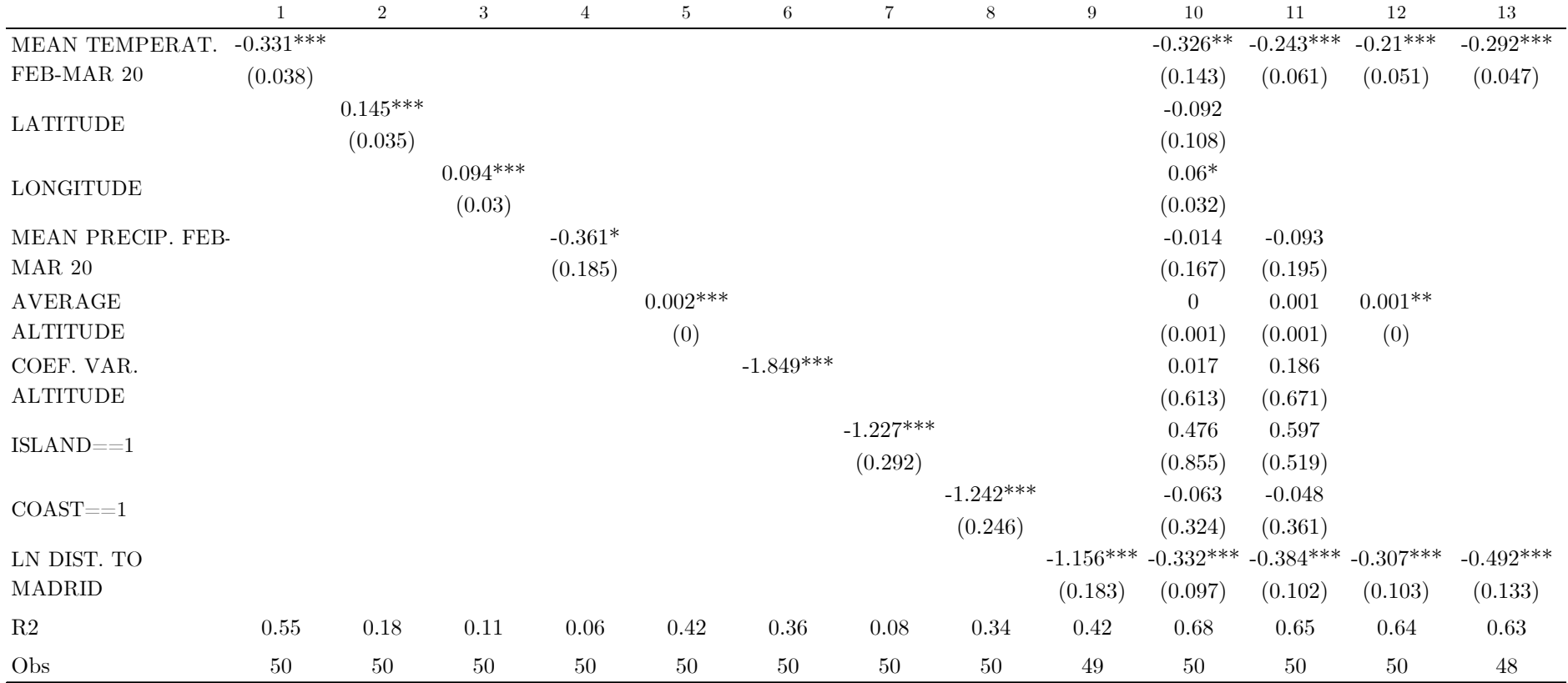

Notes: Variables' definitions and sources are available in Table A1. Robust standard errors are in parenthesis.

Table A2

Depedent variable: Log of accumulated deaths related to COVID19/100000 inhab. on April 1, 2020

$\begin{array}{cccc} & \text { Canarias } & \text { CCAA } & \text { CCAA } \\ \text { Canarias } & \text { and } & \text { fixed } \\ \text { excluded } & \text { Madrid } & \text { fixed } & \text { effects } \\ \text { excluded } & \text { effects } & \text { clustered }\end{array}$

\begin{tabular}{|c|c|c|c|c|c|c|c|c|c|c|c|c|c|}
\hline & 1 & 2 & 3 & 4 & 5 & 6 & 7 & 8 & 9 & 10 & 11 & 12 & 13 \\
\hline MEAN TEMPERAT. & $-0.331^{* * *}$ & $-0.443^{* * *}$ & $-0.317^{* * *}$ & $-0.324^{* * *}$ & $-0.249^{* * *}$ & $-0.268^{* * *}$ & $-0.35^{* * *}$ & $-0.277^{* * *}$ & $-0.256^{* * *}$ & $-0.366^{* * *}$ & $-0.358^{* * *}$ & $-0.225^{*}$ & $-0.225^{*}$ \\
\hline FEB-MAR 20 & $(0.038)$ & $(0.063)$ & $(0.041)$ & $(0.038)$ & $(0.043)$ & $(0.046)$ & $(0.044)$ & $(0.051)$ & $(0.044)$ & $(0.045)$ & $(0.044)$ & $(0.122)$ & $(0.112)$ \\
\hline LATITUDE & & $\begin{array}{c}-0.113^{* * *} \\
(0.042)\end{array}$ & & & & & & & & & & & \\
\hline LONGITUDE & & & $\begin{array}{c}0.028 \\
(0.034)\end{array}$ & & & & & & & & & & \\
\hline MEAN PRECIP. FEB- & & & & $-0.272^{* *}$ & & & & & & & & & \\
\hline MAR 20 & & & & $(0.124)$ & & & & & & & & & \\
\hline AVERAGE & & & & & $0.001^{* * *}$ & & & & & & & & \\
\hline ALTITUDE & & & & & $(0)$ & & & & & & & & \\
\hline COEF. VAR. & & & & & & $-0.724^{*}$ & & & & & & & \\
\hline ALTITUDE & & & & & & $(0.367)$ & & & & & & & \\
\hline ISLAND $==1$ & & & & & & & $\begin{array}{c}0.407 \\
(0.418)\end{array}$ & & & & & & \\
\hline $\mathrm{COAST}==1$ & & & & & & & & -0.411 & & & & & \\
\hline CUASI==1 & & & & & & & & $(0.274)$ & & & & & \\
\hline LN DIST. TO & & & & & & & & & $-0.392^{* * *}$ & & & & \\
\hline MADRID & & & & & & & & & $(0.109)$ & & & & \\
\hline $\mathrm{R} 2$ & 0.55 & 0.6 & 0.56 & 0.59 & 0.6 & 0.59 & 0.56 & 0.58 & 0.61 & 0.54 & 0.54 & 0.8 & 0.8 \\
\hline Obs & 50 & 50 & 50 & 50 & 50 & 50 & 50 & 50 & 50 & 48 & 47 & 50 & 50 \\
\hline
\end{tabular}

Notes: Variables' definitions and sources are available in Table A1. Robust standard errors are in parenthesis, except in column 13, which reports standard errors clustered at the autonomous community level.. 
Table A3

Depedent variable: Log of accumulated deaths related to COVID19/100000 inhab. on April 1, 2020

$\begin{array}{ccc}\text { Canarias } & \begin{array}{c}\text { Canarias } \\ \text { and Madrid } \\ \text { excluded }\end{array} & \begin{array}{c}\text { Canarias } \\ \text { and Madrid } \\ \text { excluded }\end{array}\end{array}$

\begin{tabular}{lccccc} 
& 1 & 2 & 3 & 4 & 5 \\
\hline LN DIST. TO MADRID & $-0.851^{* * *}$ & $-1.156^{* * *}$ & $-0.891^{* * *}$ & $-1.426^{* * *}$ & $-0.739^{* * *}$ \\
& $(0.191)$ & $(0.183)$ & $(0.26)$ & $(0.236)$ & $(0.235)$ \\
MEAN TEMPERAT. & & & & & $-0.264^{* * *}$ \\
FEB-MAR 20 & & & & & $(0.052)$ \\
R2 & 0.39 & 0.42 & 0.35 & 0.42 & 0.62 \\
Obs & 50 & 49 & 48 & 47 & 47 \\
\hline
\end{tabular}

Notes: Variables' definitions and sources are available in Table A1. Robust standard errors are in parenthesis.

Table A4

Depedent variable: Log of accumulated deaths related to COVID19/100000 inhab. on April 1, 2020

\begin{tabular}{|c|c|c|c|c|c|c|c|c|c|c|c|c|}
\hline & 1 & 2 & 3 & 4 & 5 & 6 & 7 & 8 & 9 & 10 & 11 & 12 \\
\hline LOG POPUL. 2019 & $\begin{array}{l}-0.383^{*} \\
(0.225)\end{array}$ & & & & & & & & & & & \\
\hline $\begin{array}{l}\text { LOG POP. DENSITY. } \\
2019\end{array}$ & & $\begin{array}{l}-0.293^{*} \\
(0.149)\end{array}$ & & & & & & & & & & \\
\hline LOG GDP pc 2017 & & & $\begin{array}{l}1.898^{* * *} \\
(0.645)\end{array}$ & & & & & & & & & \\
\hline $\begin{array}{l}\text { POP. CONCENTR. } \\
2019\end{array}$ & & & & $\begin{array}{c}0.031^{* * *} \\
(0.009)\end{array}$ & & & & & & & & \\
\hline AVERAGE PM $2.5 \mu \mathrm{m}$ & & & & & $\begin{array}{l}-0.076^{*} \\
(0.039)\end{array}$ & & & & & & & \\
\hline 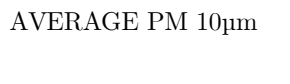 & & & & & & $\begin{array}{l}-0.052 \\
(0.032)\end{array}$ & & & & & & \\
\hline POPUL.> $64(\%)$ & & & & & & & $\begin{array}{l}0.076^{*} \\
(0.042)\end{array}$ & & & & & \\
\hline AGRIC. EMPL. (\%) & & & & & & & & -0.041 & & & & \\
\hline 2017 & & & & & & & & $(0.029)$ & & & & \\
\hline INDUST. EMPL. (\%) & & & & & & & & & $0.065^{* *}$ & & & \\
\hline 2017 & & & & & & & & & $(0.024)$ & & & \\
\hline COMM. REST. & & & & & & & & & & $-0.088^{* * *}$ & & \\
\hline HOTELS (\%) & & & & & & & & & & $(0.021)$ & & \\
\hline LOG PASSANGERS & & & & & & & & & & & $-0.055^{* *}$ & \\
\hline Feb-Mar & & & & & & & & & & & $(0.027)$ & \\
\hline LOG PASSANG./POP. & & & & & & & & & & & & $-0.829^{* *}$ \\
\hline Feb-Mar & & & & & & & & & & & & $(0.388)$ \\
\hline $\mathrm{R} 2$ & 0.1 & 0.1 & 0.12 & 0.12 & 0.07 & 0.06 & 0.08 & 0.04 & 0.1 & 0.14 & 0.09 & 0.06 \\
\hline Obs & 50 & 50 & 50 & 50 & 45 & 50 & 50 & 50 & 50 & 50 & 50 & 50 \\
\hline
\end{tabular}

Notes: Variables' definitions and sources are available in Table A1. Robust standard errors are in parenthesis, except in column 13, which reports standard errors clustered at the autonomous community level.. 


\section{Table A5}

Depedent variable: Log of accumulated deaths related to COVID19/100000 inhab. on April 1, 2020

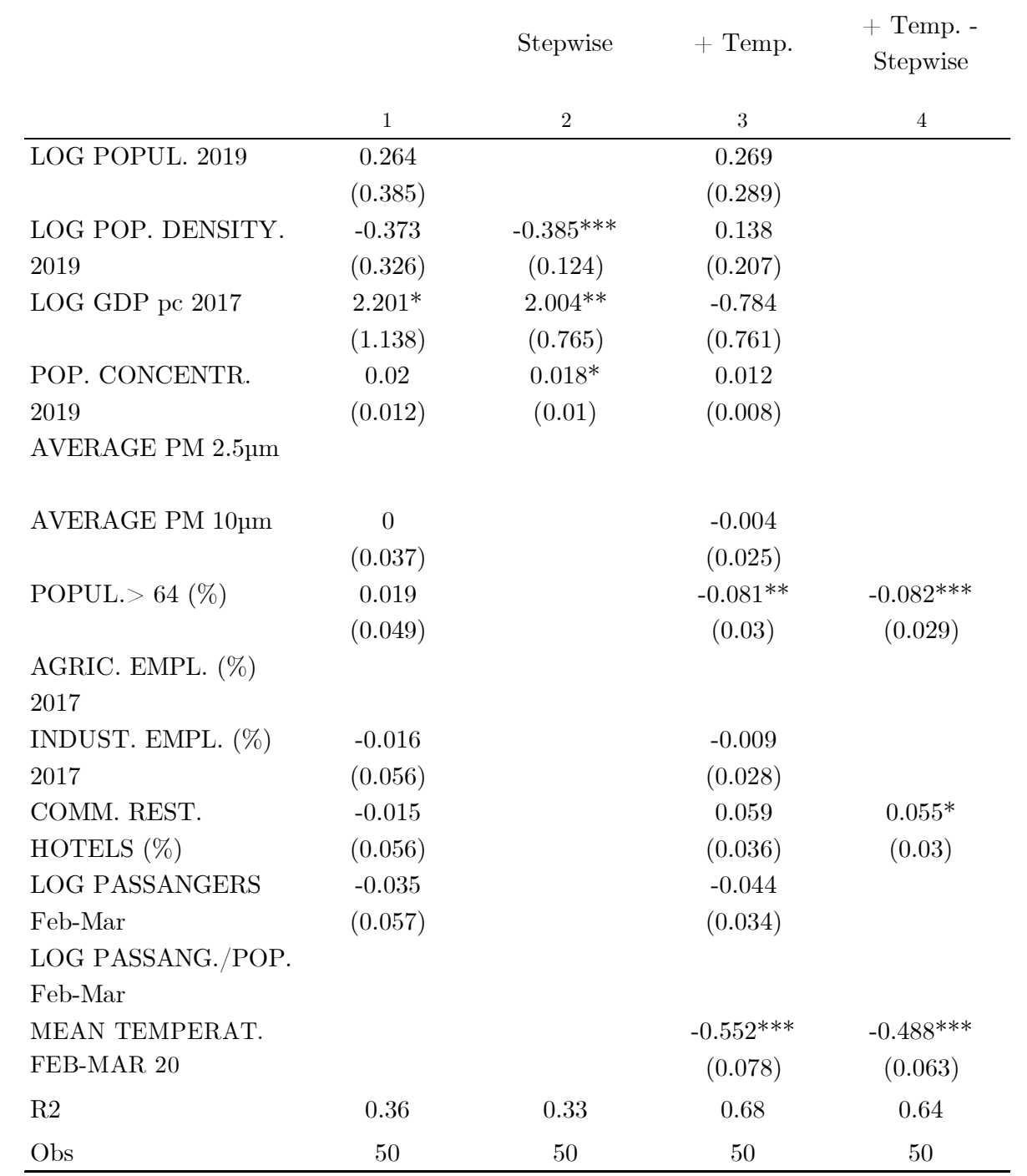

Notes: Variables' definitions and sources are available in Table A1. Robust standard errors are in parenthesis, except in column 13, which reports standard errors clustered at the autonomous community level. 